\title{
A System of Indoleamine-Accumulating Neurons in the Rabbit Retina
}

\author{
Julie H. Sandell* and Richard H. Masland* $\dagger$ \\ *Neurosurgical Service, Massachusetts General Hospital, and * †Department of Physiology, Harvard Medical \\ School, Boston, Massachusetts 02114
}

\begin{abstract}
The indoleamine-accumulating neurons of the rabbit retina were labeled by intraocular injection of 5,7-dihydroxytryptamine (5,7DHT). The retinas were fixed with $2.5 \%$ paraformaldehyde and $0.2 \%$ glutaraldehyde and inspected by fluorescence microscopy. Five kinds of cell accumulated the indoleamine. They were labeled to essentially the same brightness and remained so despite variations in the concentration at which 5,7-DHT had been applied or the duration of its application. Experiments in which 5,7-DHT was applied to retinas incubated in vitro gave identical results. To see the whole shape of the cells, we visually guided micropipettes to the fluorescent cell bodies and injected the cells with Lucifer yellow CH. To study the cells as a population, we used a new method in which the fluorescence of 5,7-DIIT is photochemically converted to an insoluble diaminobenzidine product. The dendrites of all of the indoleamine-accumulating cells were then simultaneously visible.
\end{abstract}

Used together, these techniques revealed an interrelated system of indoleamine-accumulating neurons. All of the cells contribute processes to a dendritic plexus that lies at the inner margin of the inner plexiform layer. The plexus is roughly $4 \mu \mathrm{m}$ thick. It is pierced by the stalks of the Müller cells and is occasionally interrupted by ganglion cell bodies, where they extend above the average margin of the ganglion cell layer. Otherwise it fills much of the space at the junction of the plexiform and ganglion cell layers.

The type 1 and type 2 cells are amacrine cells with cell bodies at the inner margin of the inner nuclear layer. They have 5-8 radially branching primary dendrites which extend horizontally across the inner plexiform layer before descending to join the dendritic plexus. They differ from each other in cell body shape, dendritic morphology, and the course of their dendrites within the inner plexiform layer. Each has a "displaced" counterpart, with a morphology similar to the type 1 or type 2 cell but with a cell body located in the ganglion cell layer. The displaced cells are separate functional elements because, in contrast to the type 1 and type 2 cells, they have no dendrites (and hence can have no synaptic connections) in the outer part of the inner plexiform layer.

The fifth kind of cell (type 3) appears not to have been described before. Its cell body is located at the outer margin of the inner nuclear layer. A single stalk extends through the inner nuclear and plexiform layers. Its proximal terminal is intertwined with processes of the other indoleamine-accumulating cells in the dendritic plexus. Processes also ramify within the outer plexiform layer, in a flat round tree up to $1400 \mu \mathrm{m}$ in diameter. Although type 3 cells are infrequent, they have exten-

\footnotetext{
Received Jan. 21, 1986; revised Apr. 14, 1986; accepted Apr. 17, 1986.

Supported by NIH Fellowship F32 EY05808-01 and Grant RO1 EY01075-12. We thank Nancy Madigan for skilled technical assistance.

Correspondence should be addressed to Dr. Julie H. Sandell, Wellman Building 429, Massachusetts General Hospital, Boston, MA 02114.

Copyright (C) 1986 Society for Neuroscience $0270-6474 / 86 / 113331-17 \$ 02.00 / 0$
}

sive branching; a single cell supports over 1.4 linear $\mathrm{cm}$ of processes in the outer plexiform layer.

The distribution and spacing of each kind of indoleamineaccumulating cell was analyzed quantitatively.

These 5 cells have in common the accumulation of 5,7-DHT; a common pattern of dendritic morphology and curvature; and a shared participation in the dendritic plexus at the junction of the inner plexiform and ganglion cell layers. The cells presumably have functions in common. The position and course of their dendrites, however, indicate that the connections of the cells differ. One possibility is that the cells reflect 5 pathways to a common effector site.

A central question for understanding the retina's physiology is why the use of so many amacrine cell neurotransmitters is required (see Brecha, 1983; Brecha and Karten, 1983; Ehinger, 1983). Among the many possibilities, the most obvious is that ncurotransmitters give different physiological characteristics to synapses that subserve different functions within the retina's circuits. In some cases a given neurotransmitter is associated with a unique morphological class of amacrine cell. Since different morphologies imply different physiological functions, it is easy to imagine that the functional requircments of the cclls' synapses would also be different. In other cases, though, the matching of neurotransmitters with morphologies is not unique. In this paper we describe a situation in which a single neurotransmitter is contained in not 1 but 5 retinal cells - cells with distinctly different morphologies and thus differing connectivity. Our studies had 2 purposes. The first was simply to describe the cell population in as precise a way as possible. It is now clear that the density and overlap of retinal neurons contain important clues to their functions (Hughes, 1975; Masland et al., 1984a, b; Tauchi and Masland, 1984; Vaney, 1985; Wässle et al., 1978, 1981a, b), and a new method made it possible for us to visualize the cell population in clear detail. The second was to see what these 5 cells might have in common other than a putative neurotransmitter.

Retinal neurons that accumulate serotonin were first observed by Ehinger and Florén (1976, 1980) using classical fluorescence histochemical methods. The cells had the appearance of amacrine cells, with the greatest concentration of fluorescent dendrites located at the lowest level of the inner plexiform layer. That the content of the cells was an indoleamine was suggested by the color of their fluorescence and was supported by their labeling with a series of indoleamine derivatives. These included 5,7-dihydroxytryptamine (5,7-DHT), the molecule used to mark the cells in the experiments to be described here. Ehinger and Florén's work has been confirmed, in various species, by autoradiographic techniques (Ehinger et al., 1982; Mitchell and Redburn, 1985; Osborne, 1984; Redburn, 1984; Thomas and Redburn, 1979). Because the rabbit retina's endogenous content of serotonin is small, Ehinger and Floren gave the cells the neutral name "indoleamine-accumulating," against the possi- 


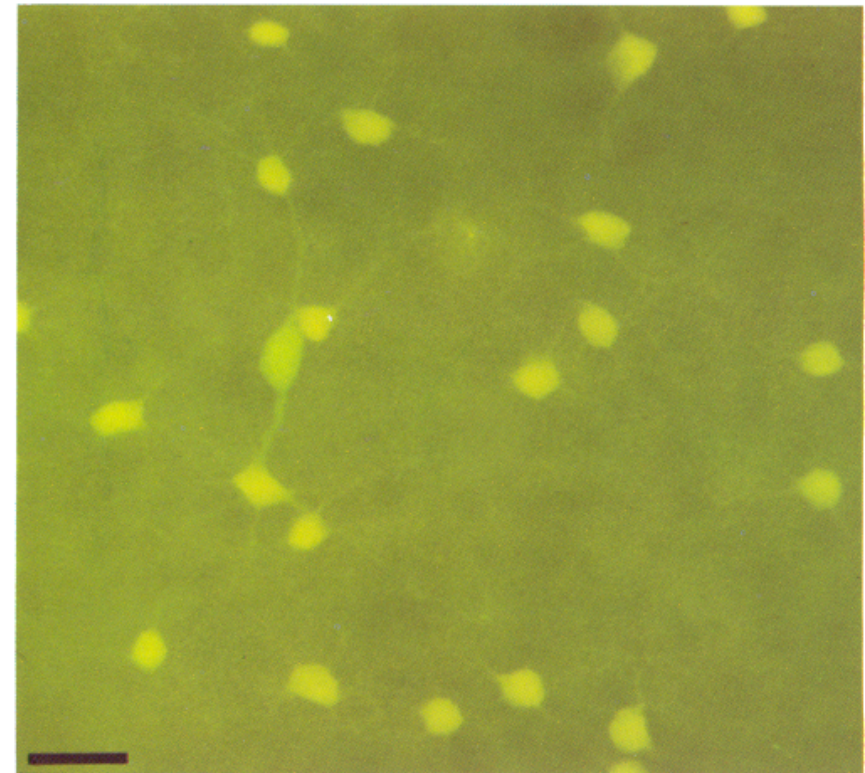

Figure 1. Fluorescence micrograph of a rabbit retina after exposure of the retina to 5,7-DHT. Flat-mount view. The cells that have accumulated 5,7-DHT fluoresce yellow. A cell containing endogenous catecholamine fluoresces green. These cells are located at the inner margin of the inner nuclear layer. Scale, $30 \mu \mathrm{m}$.

bility that the true neurotransmitter might be an indoleamine other than serotonin (Florén, 1979a, b; Florén and Hansson, 1980). However, authentic serotonin has now been shown to be present in other mammalian retinas; serotonin accumulated by retinas is released in a $\mathrm{K}^{+}$-stimulated, $\mathrm{Ca}^{2+}$-dependent manner; retinas contain biochemically demonstrable serotonin receptors; and serotonin antagonists at micromolar concentrations affect the activity of the retinal ganglion cells (Ames and Pollen, 1969; Blazynski et al., 1985; Brunken and Daw, 1985; Ehinger and Florén, 1978; Osborne, 1981, 1984; Osborne and Patel, 1984; Redburn, 1984; Thier and Wässle, 1984; Thomas and Redburn, 1980). While we will retain Ehinger and Florén's terminology, it seems likely that serotonin is the indoleamine contained in the indoleamine-accumulating cells.

\section{Materials and Methods}

Adult New Zealand White rabbits of either sex were anesthetized with intravenous sodium pentobarbital $(30 \mathrm{mg} / \mathrm{kg})$. The corneas were anesthetized with a drop of ophthalmic proparcaine. 5,7-DHT (Sigma), 20 $\mu 1$, dissolved in $0.9 \%$ saline together with $1 \mathrm{mg} / \mathrm{ml}$ ascorbic acid was injected into each eye via a Hamilton syringe. The total amount of 5,7DHT injected varied $(1,3,10,30,50,100 \mu \mathrm{g})$. Unless otherwise specified the amount was $50 \mu \mathrm{g}$, to yield a vitreal concentration (assuming a vitreal volume of $1.5 \mathrm{ml}$ ) of $81.8 \mu \mathrm{M}$. Anesthesia was maintained throughout the survival period, which varied from 1 to $4 \mathrm{hr}$; the standard survival was $2 \mathrm{hr}$. For enucleation the pentobarbital was supplemented by ether. The eyes were removed and hemisected, and the vitreous body was lifted away. The posterior eyecup was immersed in an oxygenated bicarbonate buffer resembling cerebrospinal fluid in its electrolytes (Ames and Nesbett, 1981). A smooth glass rod was used to tease the retina away from the pigment epithelium, and the retina was freed as a single sheet by cutting the optic nerve (see Ames and Nesbett, 1981; Masland and Livingstone, 1976). The retina was flattened between layers of filter paper (Tauchi and Masland, 1984) and was fixed for $1 \mathrm{hr}$ at room temperature in a freshly prepared solution containing $2.5 \%$ paraformaldehyde and $0.2 \%$ glutaraldehyde in phosphate buffer $(0.1 \mathrm{M}, \mathrm{pH}$ 7.4). The fixative was removed by repeated rinsing with phosphate buffer and the retina-filter paper sandwich was stored in buffer at $4^{\circ} \mathrm{C}$.
In control experiments we studied 4 retinas from Sprague-Dawley albino rats. The rats were anesthetized with sodium pentobarbital (45 $\mathrm{mg} / \mathrm{kg}$, intraperitoneal) and $10 \mu \mathrm{g}$ of 5,7-DHT was injected into the vitreous of each eye. The survival time was $2 \mathrm{hr}$, and the retinas were processed as described above. Two retinas from pigmented (Dutch Belted) rabbits were studied.

Other rabbit retinas were labeled by exposure to $5,7-\mathrm{DHT}$ in vitro. They were removed from the eye as described above and incubated in $20 \mathrm{ml}$ volumes of Ames medium maintained at $35^{\circ} \mathrm{C}$. After isolation the retinas were incubated in control medium for $5 \mathrm{~min}$. They were then transferred to fresh medium containing $1,3,10,30$, or $60 \mu \mathrm{M} 5,7$ DHT. Incubation with gentle agitation continued for $15,30,60$, or 120 $\mathrm{min}$. The retinas were then rinsed in fresh incubation medium for 5 min and flattened and fixed as described above.

The labeled retinas were coverslipped in phosphate buffer, vitreal surface uppermost. The coverslip's edges were sealed with nail polish. Fluorescent whole mounts were examined with a Leitz Dialux 20 epifluorescence microscope equipped with a $200 \mathrm{~W}$ mercury source and Leitz filter set H2 (excitation wavelengths, 390-490 nm; viewing wavelengths, $\geq 515 \mathrm{~nm}$ ). Under these conditions, cells that have accumulated indoleamines appear golden yellow, while cells that contain catecholamines appear green (Furness et al., 1977b). In unlabeled rabbit retinas and in rat retinas only green cells were seen. No differences were observed between retinas from albino and pigmented rabbits.

\section{Photooxidation of diaminobenzidine}

As will be described, the fluorescent indoleamine-accumulating cells could be rendered visible by ordinary bright-field microscopy if they were irradiated with blue light in the presence of 3,3'-diaminobenzidine (DAB). A piece of retina containing fluorescent cells labeled with 5,7DHT was rinsed in Tris buffer $(0.1 \mathrm{M}, \mathrm{pH} 8.2)$ and placed with the vitreal surface uppermost on a glass slide. Excess Tris was blotted off and a drop of DAB (Sigma grade II, $1.5 \mathrm{mg} / \mathrm{ml}$ in $0.1 \mathrm{M}$ Tris buffer, $\mathrm{pH}$ 8.2 ) was placed on the retina. The retina was illuminated on the microscope stage, with no coverslip, as for fluorescence microscopy, using Leitz filter set $\mathrm{H} 2$ and a Zeiss $10 \times$ Neofluor objective, numerical aperture 0.30 . The irradiated field was approximately $1200 \mu \mathrm{m}$ in diameter. (Practical considerations dictated the choice of objective. At lower magnification the irradiated field is larger, but the intensity of irradiation less.) When the illumination was begun, the fluorescence of the cells faded and was replaced by an opaque, reddish-brown DAB reaction product. The progress of the reaction was monitored at $10 \mathrm{~min}$ intervals by rinsing away the DAB solution and examining the retina with transmitted light. When the result appeared optimal (20-40 min), the reaction was terminated by immersing the piece of retina in Tris buffer. The conversion reaction occurred within the field that was irradiated but not elsewhere in the piece of tissue.

For whole-mounts, reacted pieces of retina were floated onto gelatinized slides, air-dried, dehydrated with alcohols, cleared in xylenes, and coverslipped with Krystalon (Harleco). For sectioning, reacted pieces of retina were dehydrated with alcohol under a coverslip (to prevent curling) and then embedded in methacrylate (JB4, Polysciences). Radial sections were cut at $2-10 \mu \mathrm{m}$ with a rotary microtome. Some sections were lightly counterstained with cresyl violet $(0.2 \%)$ or methylene blue $(1 \%)$, while others were coverslipped without counterstaining. DAB preparations were photographed with Kodak Panatomic X-32 or Technical Pan 2415 film, developed for medium contrast. Drawings of DABlabeled cells were made at a magnification of 12.5 or $7.1 \mu \mathrm{m}$ to the inch using a gridded eyepiece reticle and appropriately gridded paper (Tauchi and Masland, 1984).

\section{Cell injections}

A piece of fixed retina containing cells labeled with 5,7-DHT was placed on moist black filter paper in a small petri dish. The vitreal surface was uppermost. The retina was covered with a drop of phosphate buffer. The edges of the piece of retina were held down by a moist cotton thread, which served as a return electrode and also created a shallow well that contained the drop of buffer. The petri dish was placed on the fixed stage of a modified Leitz Laborlux 12 microscope. The retina was viewed through a Nikon $40 \times$ objective (free working distance, $10 \mathrm{~mm}$ ) at a total magnification of $310 \times$.

Glass micropipettes were prepared using a Kopf vertical puller. The tip was filled by capillary action with a saturated solution of Lucifer 
yellow CH (gift of W. Stewart) and the barrel was filled with $50 \mathrm{~mm}$ Tris- $\mathrm{HCl}$ ( $\mathrm{pH} 7.5$ ) with $0.25 \mathrm{M} \mathrm{KCl}$. The pipette resistance was typically $125 \mathrm{M} \Omega$. The labeled cells and the pipette filled with Lucifer yellow were simultaneously visible when illuminated via the $\mathrm{H} 2$ filter set. Fluorescent cells were penetrated under visual control and were filled with dye by a combination of diffusion and electrophoresis, as described previously (Tauchi and Masland, 1984, 1985). Pieces of retina containing injected cells were coverslipped in phosphate buffer. The cells were photographed or were drawn at a magnification of $20 \mu \mathrm{m}$ to the inch, using a gridded eyepiece reticle and appropriately gridded paper.

\section{Cell counts}

The density of the indoleamine-accumulating cells was established by counting them in either fluorescent material or material reacted with DAB. Counts were made within a $200 \times 200 \mu \mathrm{m}$ eyepiece reticle at $400 \times$ magnification. Cells were assigned to separate subpopulations based on soma size, shape, and depth, and the appearance of the proximal dendrites. As will be shown, these attributes allow the various types of cell to be distinguished easily. Even for the most difficult - the type 1 and 2 cells, which both have cell bodies in the amacrine cell layer-interobserver agreement when the authors independently counted the same fields was greater than $95 \%$.

\section{Sample of retinas}

A total of 59 rabbit retinas were exposed to 5,7-DHT and then studied by fluorescence microscopy. Pieces from 33 of them were then reacted with $\mathrm{DAB}$ and studied further. Two hundred and seventy-nine fields were reacted with DAB. Cell injections were carried out in 32 retinas.

\section{Results}

When the rabbit retina was exposed to 5,7-DHT and then fixed with mixed aldehydes, a substantial population of cells showed the yellow fluorescence characteristic of indoleamine-containing cells. A small population of cells fluoresced green. The color of their fluorescence was that of dopamine (Furness et al., 1977a, b), and they had the frequency and fusiform shape of the dopamine-containing amacrine cell previously studied by histofluorescence methods and by immunohistochemical detection of tyrosine hydroxylase (Brecha et al., 1984; Ehinger and Åberg, 1981; Negishi et al., 1984). Injecting them with Lucifer yellow (Tauchi and Masland, 1986) revealed the dendritic shape of the dopamine-containing amacrine cell (Brecha et al., 1984). The yellow cells and green cells are easily distinguished by color and soma shape (Fig. 1). Our concern in the experiments to be described here was with the yellow cells, which are unmistakably the indoleamine-accumulating cells first described by Ehinger and Florén (1976).

Among the indoleamine-accumulating cells, 5 subpopulations could be distinguished. Two have cell bodies located in the position of amacrine cells; 2 have cell bodies located in the ganglion cell layer; and 1 had cell bodies located at the outer margin of the inner nuclear layer. The fluorescence of the 5 cells was equally bright and developed with the same time course. We varied the intravitreal concentration of 5,7-DHT from 16.3 to $163.6 \mu \mathrm{M}$ and the survival time from 1 to $4 \mathrm{hr}$. Retinas were also labeled in vitro with 5,7-DHT concentrations ranging from 1 to $60 \mu \mathrm{M}$ and incubation times from $15 \mathrm{~min}$ to $2 \mathrm{hr}$. These manipulations produced retinas that ranged from completely unlabeled to those in which the background fluorescence was so bright that the labeled cells were obscured. No new cell types appeared under any of these conditions, and the 5 subpopulations of labeled cell were always equally bright. In order for the second to be true, the overall kinetics of 5,7-DHT accumulation by the cells must be the same. Although one can contrive a hypothetical situation in which differing $K_{\mathrm{m}}$ 's or $V_{\max }$ 's would be exactly counterbalanced by differing rates of degradation or secretion of 5,7-DHT, it is more likely that the 5 cells possess the same carrier mechanism.

Our primary goal was to learn the cells' whole shapes, and


Figure 2. Indoleamine-accumulating cells before (top) and after (bottom) the photochemically catalyzed DAB reaction. A green, catecholamine-containing cell was present in the fluorescent field (arrow); it did not react with DAB. Scale, $25 \mu \mathrm{m}$.

the interrelationships among them. For this we used 2 complementary methods. The first employed a newly discovered photochemical reaction in which the fluorescence of 5,7-DHT is interchanged for a diaminobenzidine reaction product. This method shows both the cell bodies and the dendrites of the indoleamine-accumulating cells - and shows the whole indoleamine-accumulating population simultaneously, so that the interrelationships among the cells may be visualized. Precisely because the whole population is revealed, however, the entire dendritic tree of an individual cell cannot be examined; the distal dendrites of neighboring cells obscure each other. To see individual cells in isolation we used visually guided injection of Lucifer yellow (Tauchi and Masland, 1984). The fluorescent cell 

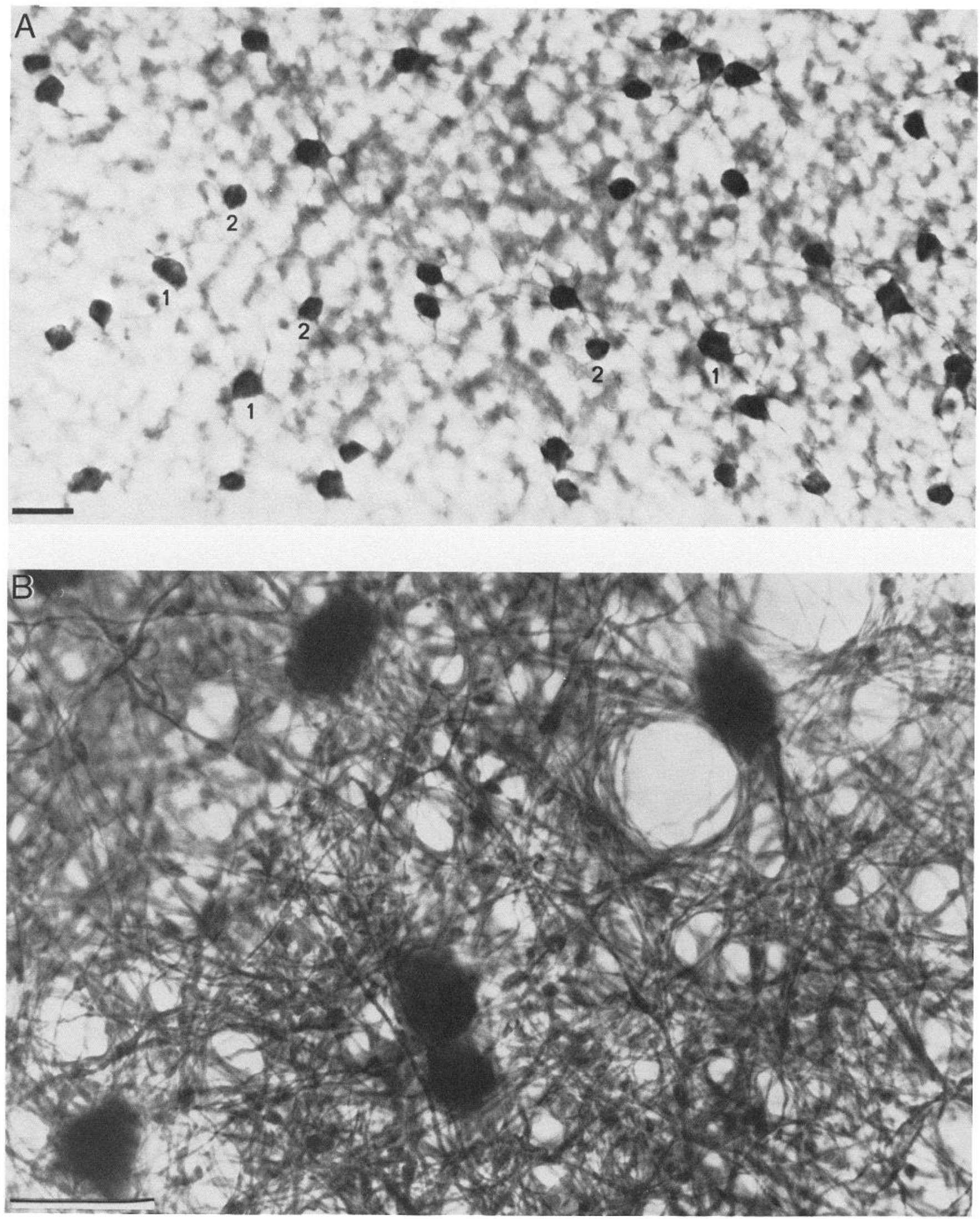

Figure 3. A, Mosaic of type 1 and type 2 cells. DAB-reacted material. Type 1 cells $(1)$ have larger cell bodies. They appear less regular in outline than the cell bodies of the type 2 cells (2). Scale, $20 \mu \mathrm{m}$. B. Plexus of indoleamine-accumulating dendrites. The plexus is located at the base of the inner plexiform layer. The dendrites form a dense meshwork punctuated by small holes that contain Müller cell bodies. The larger holes surround occasional ganglion cell bodies that protrude above the average margin of the ganglion cell layer. The indoleamine-accumulating cell bodies are out of focus above the plexus. Scale, $20 \mu \mathrm{m}$. 


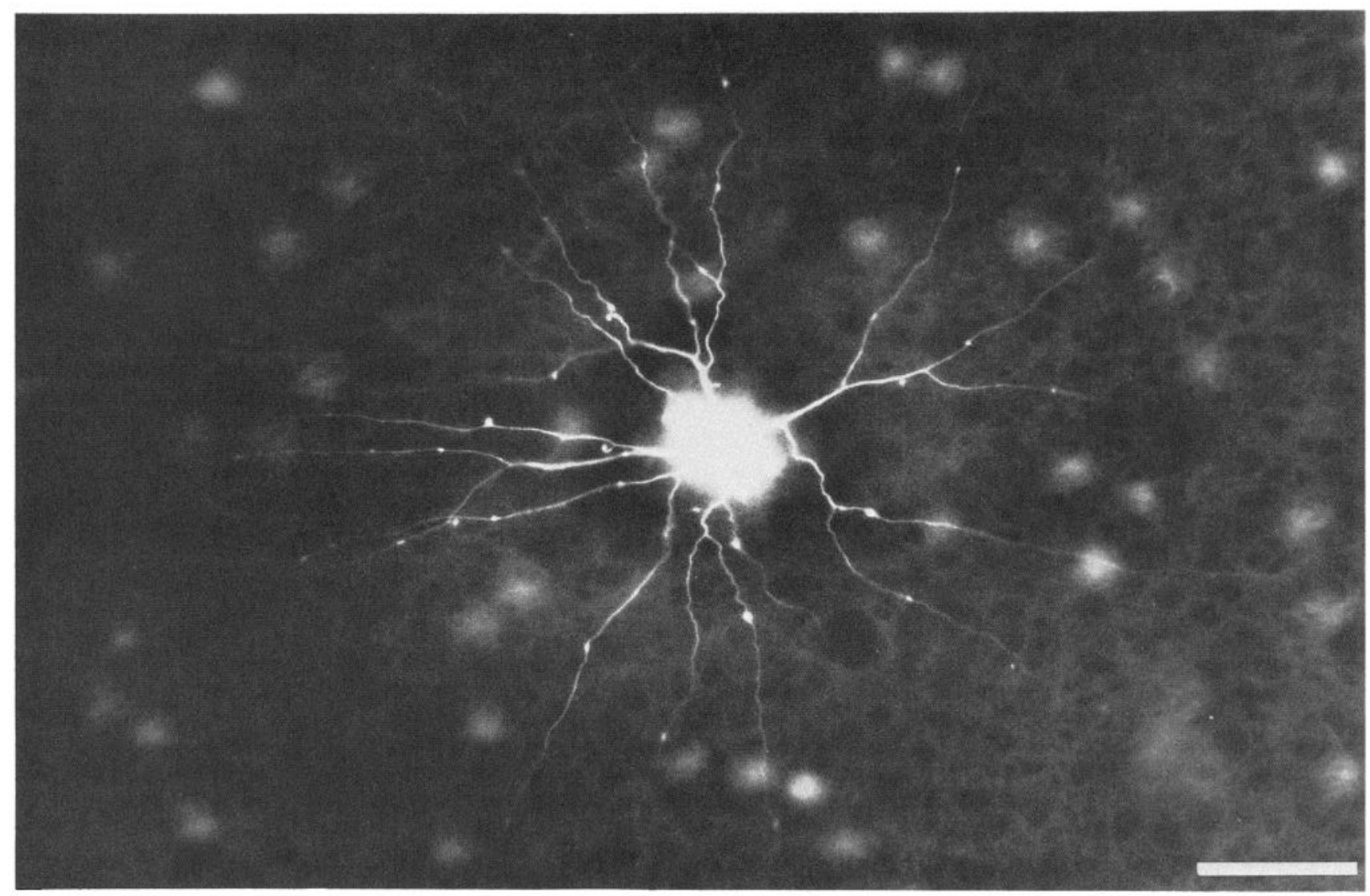

Figure 4. Type 1 indoleamine-accumulating cell injected with Lucifer yellow. In order for the micrograph to show as much of the dendritic tree as possible, a displaced type 1 cell is shown. (The displaced cells have flatter dendritic trees than the conventionally placed ones.) Scale, $50 \mu \mathrm{m}$.

body was impaled while the cell and micropipette were viewed in the fluorescence microscope, and the dye was then injected to fill the cell's dendrites.

\section{Photoconversion of 5,7-DHT fluorescence}

When cells containing 5,7-DHT fluorescence are irradiated in the presence of DAB by the intense blue light of a fluorescence microscope, the fluorescence fades and is replaced by an opaque DAB reaction product. Since the reaction is carried out under the microscope, its progress can be observed visually. Only the indoleamine-accumulating cells participate in it (Fig. 2). The arrow in the top half of the figure points to a green (dopaminergic) neuron, in the midst of yellow cells that have accumulated 5,7-DHT. After the DAB reaction (bottom), the indoleamine-accumulating cells, and only those cells, are filled with the opaque reaction product.

The reaction appears to occur only when the tissue is irradiated with light of a wavelength that excites the aldehydeinduced fluorescence of 5,7-DHT: A DAB product was generated when the tissue was irradiated via Leitz filter set $\mathrm{H} 2$ or D (nominal wavelengths, 390-490 and 355-425 nm, respectively), but not when irradiated via filter sets A or N2 (340-380 or 530$560 \mathrm{~nm})$. The reaction occurs more rapidly when the cells appear bright in the microscope and slowly or not at all when the cells are $\operatorname{dim}$. We also confirmed the specificity of the reaction in 2 control experiments: (1) Green (catecholaminergic) fluorescent amacrine cells are also visible in rabbit retinas that have been fixed without any exposure to 5,7-DHT; no opaque reaction product appears when these preparations are illuminated in the presence of DAB. (2) The rat retina apparently does not contain indoleamine-accumulating cells (Ehinger et al., 1982), and as was expected, rat retinas exposed to 5,7-DHT do not contain any yellow cells. However, they do contain cells that fluoresce green. These retinas are also devoid of cellular DAB product despite prolonged $(>2 \mathrm{hr}$ ) illumination in the presence of DAB.

The reacted tissue is more conveniently studied than the fluorescent, because the DAB product does not fade. The cells' contrast is greater because the background is less. Tissue reacted with DAB can be dehydrated, cleared, and coverslipped by conventional methods, providing better optical resolution. (These manipulations induced prohibitive background in the fluorescent specimens.) The net result is an apparent amplification of the staining (Figs. 2, 3A). While the dendrites are barely visible in the best fluorescent whole-mounts, they stand out boldly after the DAB reaction.

In the DAB-reacted material, the 5 subtypes of indoleamineaccumulating cell body could be easily distinguished. They will be described in detail below. What was most striking initially was the intertwining of their dendrites into a confluent plexus at the base of the inner plexiform layer. This creates a layer of indoleamine-accumulating dendrites at the border of the inner plexiform and ganglion cell layers. It is formed of dendrites from all 5 subtypes of indoleamine-accumulating cells, which pass through the neuropil of the inner plexiform layer and then join together at that level. The plexus is best seen in whole-mount view. Because of the overlap of the indoleamine-accumulating cells' dendritic fields, the retina then appears blanketed by a thick web of indoleamine-containing processes. It is so dense that the dendrites of any individual cell can be followed within it for only a few tens of microns. The plexus is pierced by the stalks of the Müller cells. There are also less frequent larger holes. In counterstained whole-mounts, and especially in sections, these are seen to surround those ganglion cells that lie closest to the inner plexiform layer. Within the matrix of the 
Figure 5. Drawings of type 1 and type 2 indoleamine-accumulating cells that had been filled with Lucifer yellow. These cells were located in the inner nuclear layer. They were positioned adjacent to one another in the visual streak. The type 2 cell had some dendrites that branched in the outer part of the inner plexiform layer; these are indicated by dotted lines. Scale, 30 $\mu \mathrm{m}$.

plexus one can see varicosities and bundles of DAB-positive dendrites. The plexus is shown in whole-mount view in Figure $3 B$ and in sections in Figures 6 and 7.

Type 1 cells

Type 1 cells have larger somas than type 2 cells (Fig. $3 A$ ). In whole-mount view the initial segments of the primary dendrites
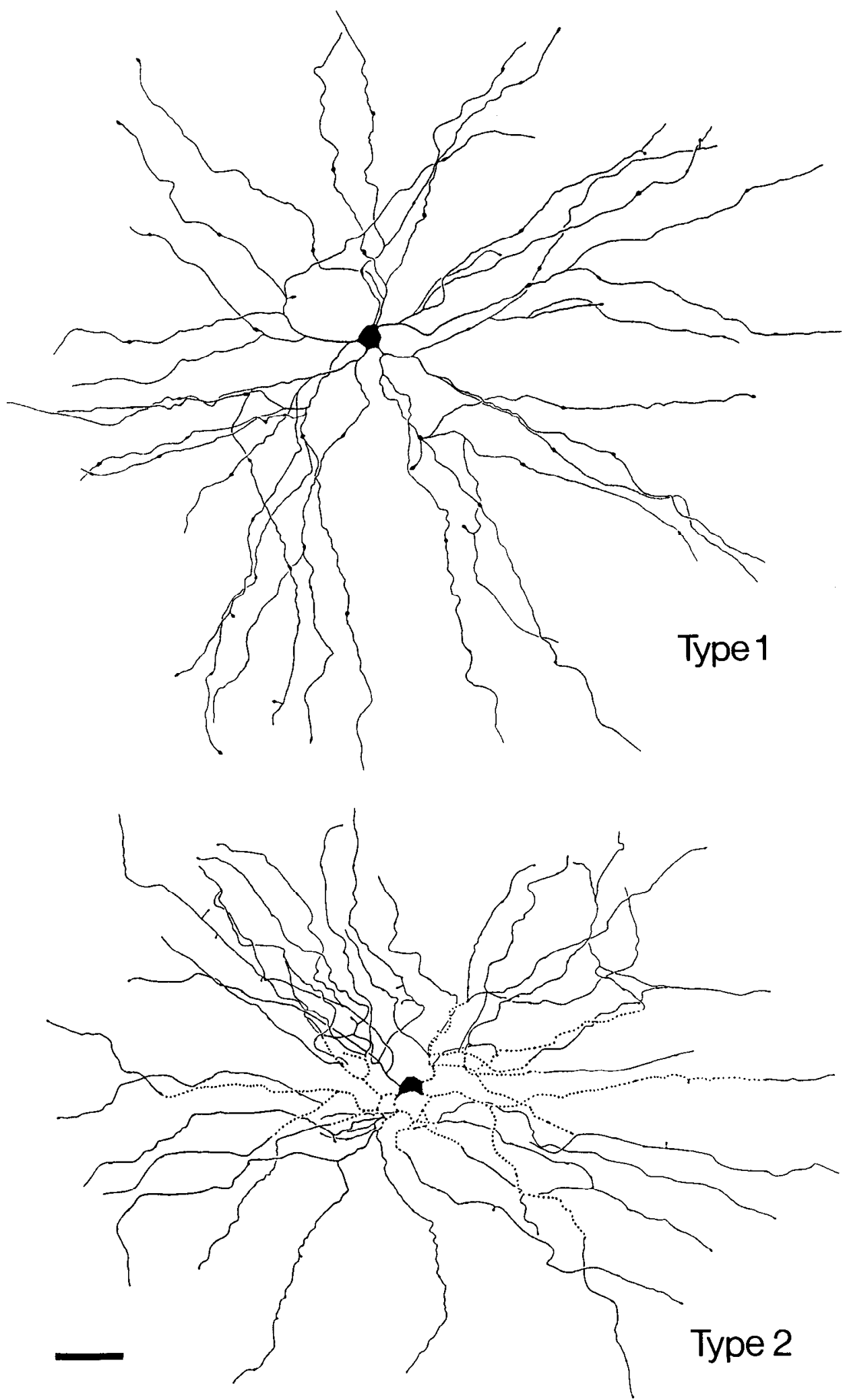

give these cell bodies an irregular shape, because they leave the cell body laterally. The morphology of a type 1 cell, as revealed by injection of Lucifer yellow, is shown in Figures 4 and 5. The dendrites are relatively straight and smooth (by amacrine cell standards), with characteristically large, infrequent varicosities. The varicosities were $1-2 \mu \mathrm{m}$ in diameter. There were an average of 46 of them in 48 Lucifer yellow-filled cells (range, 19-82). 
The dendrites also have occasional "twigs" about $4 \mu \mathrm{m}$ long, often with a small swelling on the tip. The dendrites exit horizontally from the cell body and run parallel to the retina's layers for $10-30 \mu \mathrm{m}$ (Fig. 6A). They then curve gradually across the inner plexiform layer to join the dendritic plexus just above the ganglion cell layer.

\section{Type 2 cells}

The second type of indoleamine-accumulating cell has a consistently smaller cell body than the first. In whole-mount view these somas have a smooth outline because the dendrites exit from the vitreal surface of the cell body. The dendrites of the type 2 cell are finer than those of type 1, with smaller, more frequent varicosities. The morphology of a Lucifer-filled type 2 cell is shown at the bottom of Figure 5 . An important distinguishing feature of the type 2 cell is the distribution of its dendrites within the inner plexiform layer. While some of the dendrites follow the same course as those of the type 1 cell, others run for long distances at a level just below the inner nuclear layer (Figs. $6 B, 5$ ). We hesitate to label the type 2 cell "bistratified," but it does have a greater opportunity for synaptic interaction in the outer part of the inner plexiform layer than does the type 1 cell.

\section{Displaced type 1 and type 2 cells}

A smaller number of indoleamine-accumulating cell bodies were present in the ganglion cell layer. The dendrites of these cells also join the plexus at the base of the inner plexiform layer, which in this case is directly adjacent to the displaced cell body. We have filled several dozen of these displaced cells with Lucifer yellow. All had the typical soma and dendritic morphology of the type 1 or type 2 cell. They thus appear to be counterparts of the conventionally placed type 1 and 2 cells, and we have named them as such. As will be discussed later, they are distinguished as separate cell types because their proximal dendritic trees do not contact the outer part of the inner plexiform layer.

\section{Type 3 cells}

A new type of indoleamine-accumulating neuron was also revealed by the $\mathrm{DAB}$ photooxidation reaction. Its cell body lies at the outer margin of the inner nuclear layer. Because the inner nuclear layer of the rabbit retina is thin (and these cells are infrequent), the difference in the depth of their cell bodies originally escaped our notice in fluorescent whole-mounts. In the clearer DAB material, they are more easily seen, and since recognizing their existence, we have observed them in all retinas labeled with 5,7-DHT (a total of 27 retinas, both fluorescent and DAB-reacted).

Processes of the type 3 cells connect the inner and outer plexiform layers. A photomicrograph of a type 3 cell is shown at the top of Figure 7, and serial reconstructions of 2 of them are drawn below it. A single proximal process enters the inner plexiform layer and with minimal branching reaches the plexus of type 1 and type 2 dendrites at its base. The most striking feature of the type 3 cells, however, is that they have an extensive arborization in the outer plexiform layer. These processes were instantly visible in the DAB material, because nothing else in the outer plexiform layer is stained. One of these arborizations is drawn in Figure 8. The spread of the processes of this cell was in excess of $1160 \mu \mathrm{m}$. In many cases (including the one shown in Figure 8), the absolute spread is not known because the processes clearly extend beyond the borders of the irradiated field. (For technical reasons, the diameter of this field is currently limited to $1200 \mu \mathrm{m}$.) Despite the large area covered by the arborization, the branching pattern is not sparse. The total length of the processes supported by the cell shown in Figure 8, for example, cannot be less than $1.4 \mathrm{~cm}$.

Processes destined for the outer plexiform layer exit directly
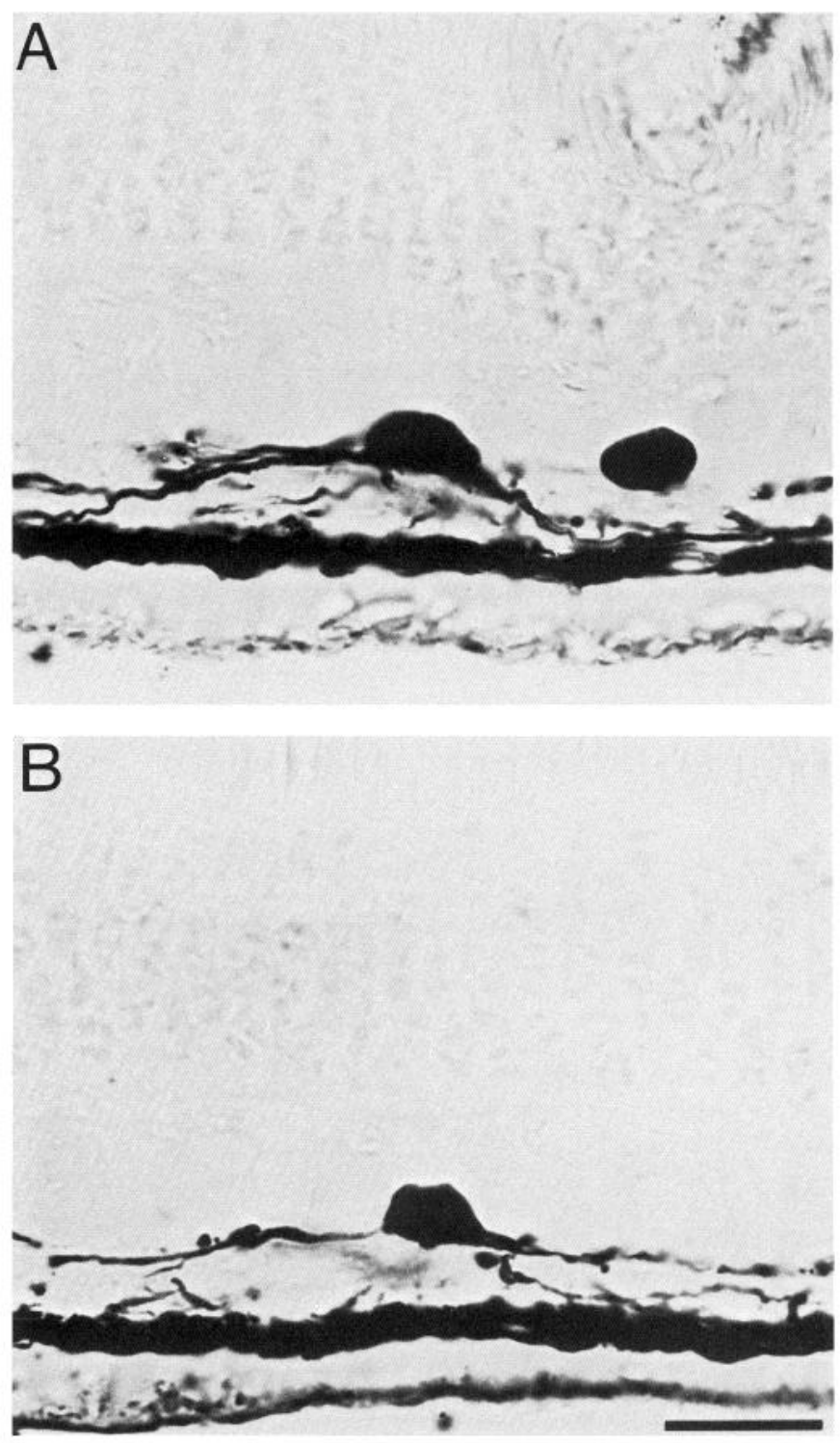

Figure 6. Vertical sections of a DAB-reacted type 1 cell $(A)$ and type 2 cell $(B)$. Both cell bodies are located at the inner margin of the inner nuclear layer, and both send dendrites to a plexus at the base of the inner plexiform layer. However, the type 2 cell also has dendrites that extend along the junction of the inner nuclear and inner plexiform layers. Scale, $15 \mu \mathrm{m}$.

from the cell body. They contain varicosities and irregular swellings, as shown in Figure 9, but no ascending terminals or other horizontal-cell-like specializations. The type 3 cell bodies and arborizations in the outer plexiform layer are more like those of amacrine cells than horizontal or bipolar cells.

\section{Cell densities and distributions}

Because of the clear differences in the size and shape of type 1 and type 2 somas, we were able to distinguish and count them in either photooxidized DAB fields or fluorescent whole-mounts. Figure 10 shows the number of type 1 and type 2 cells counted in a series of $1 \mathrm{~mm}$ circular fields that had been reacted with $\mathrm{DAB}$ at various locations on the retina. We also measured the density of the 2 cell types by counting cells at $0.5 \mathrm{~mm}$ intervals along central vertical swaths in a fluorescent whole-mount. Plots of density as a function of retinal eccentricity are shown in Figure 

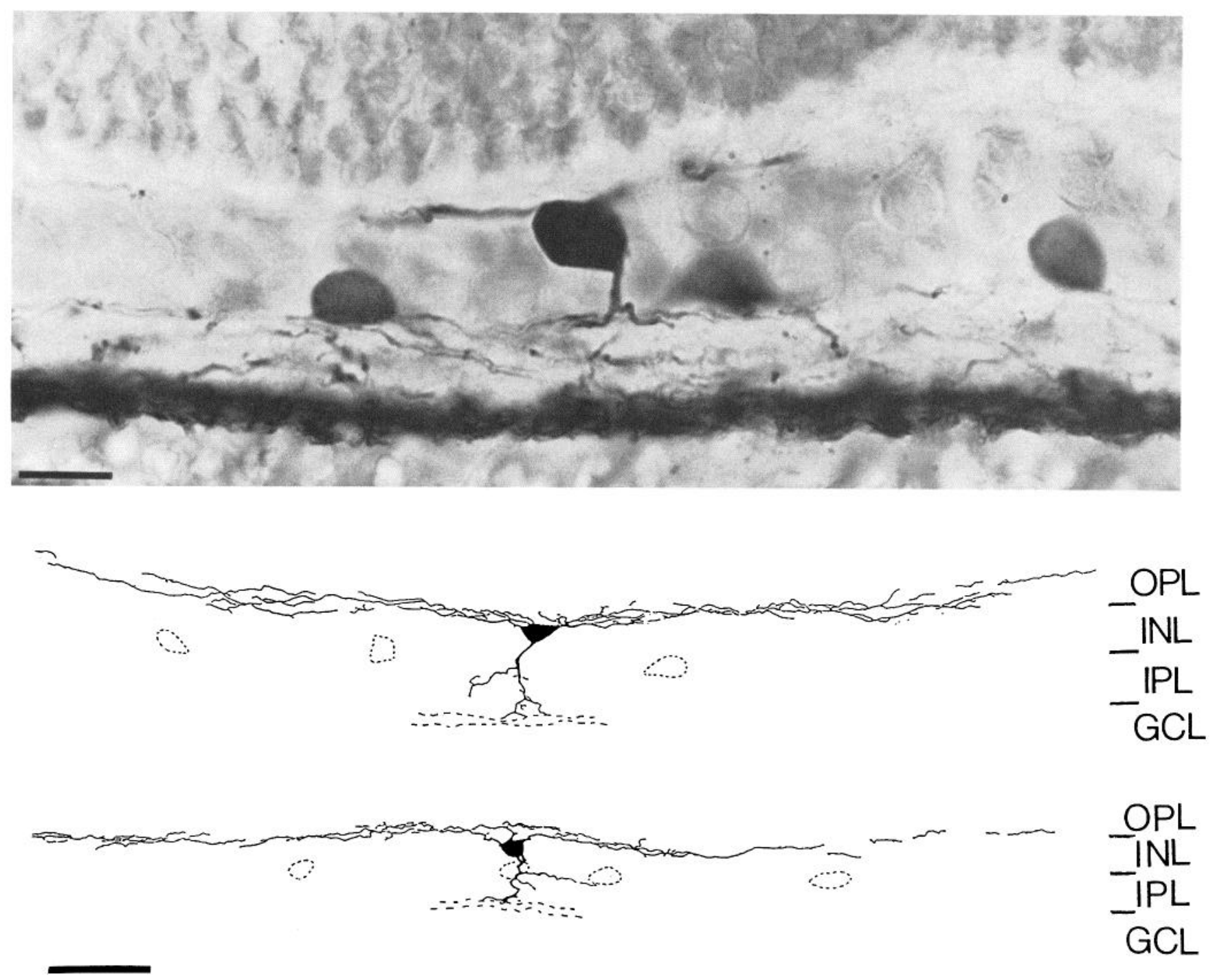

Figure 7. Type 3 indoleamine-accumulating cells. Top panel, Vertical section through a DAB-reacted cell. Its soma is located at the outer margin of the inner nuclear layer. Processes extend horizontally within the outer plexiform layer. Another process descends from the soma to the inner plexiform layer, where it branches within the plane of indoleamine-containing dendrites. Scale, $15 \mu \mathrm{m}$. Lower panel, Serial reconstructions through 2 other type 3 cells. Dendrites from three $8 \mu \mathrm{m}$ sections were drawn in both cases. Other indoleamine-accumulating cell bodies present in the sections are shown by dashed lines. $O P L$, Outer plexiform layer; $I N L$, inner nuclear layer; $I P L$, inner plexiform layer; $G C L$, ganglion cell layer. Scale, $25 \mu \mathrm{m}$.

11. The density distributions of the 2 cell types are similar, with a peak of approximately 650 cells $/ \mathrm{mm}^{2}$ in the visual streak and about 100 cells $/ \mathrm{mm}^{2}$ in the dorsal and ventral periphery. From a series of similar counts, isodensity maps for the type 1 and 2 cells were constructed (Fig. 12, $A, B$ ). Integration of the maps shown in Figure 12 showed the retina illustrated there to contain a total of 83,775 type 1 cells and 85,759 type 2 cells.

The number of labeled cells present in the retinal ganglion cell layer was counted in 4 retinas. Two retinas came from a single rabbit; there were 3079 displaced indoleamine cells in one and 3482 in the second. Two other retinas, each from a different rabbit, contained 1083 and 1630 cells. In the fourth retina, displaced type 1 and type 2 cells were plotted separately. They are shown in Figure 13, $A$ and $B$.

Type 3 cells were the least frequent subtype. The location of every type 3 cell that could be identified in a fluorescent wholemount was plotted (Fig. 13C). This retina contained a total of 295 type 3 cells. They appear to be densest in the ventral retina (where local densities as high as 6 cells $/ \mathrm{mm}^{2}$ were observed).
The paucity of type 3 cells in the visual streak, however, may be exaggerated. The thickness of the central retina may limit penetration of 5,7-DHT, so that fewer type 3 cells are labeled. The high central density of the other indoleamine-accumulating cells (taken together, more than 1300 cells $/ \mathrm{mm}^{2}$ ) may have made the type 3 cells harder to see. Finally, the somas of a small proportion of the type 1 and type 2 cells in the visual streak are found among the second, more distal row of amacrine cell bodies in the inner nuclear layer, and this may have obscured the depth difference, which is the easiest way to detect the type 3 cells in fluorescent whole-mounts. On the other hand, type 3 cells also seemed rare in the visual streak, in our sample of DAB-reacted fields, and that method shows the type 3 cells clearly. The possibility that the type 3 cells are less common in the visual streak than in the periphery must thus be left open.

The regularity of cell body spacing was evaluated for each cell type by nearest-neighbor analysis. For type 1 and type 2 cells, a DAB-reacted field $1.233 \mathrm{~mm}^{2}$ located $5 \mathrm{~mm}$ ventral to the visual streak was studied. The location of every cell was drawn, 


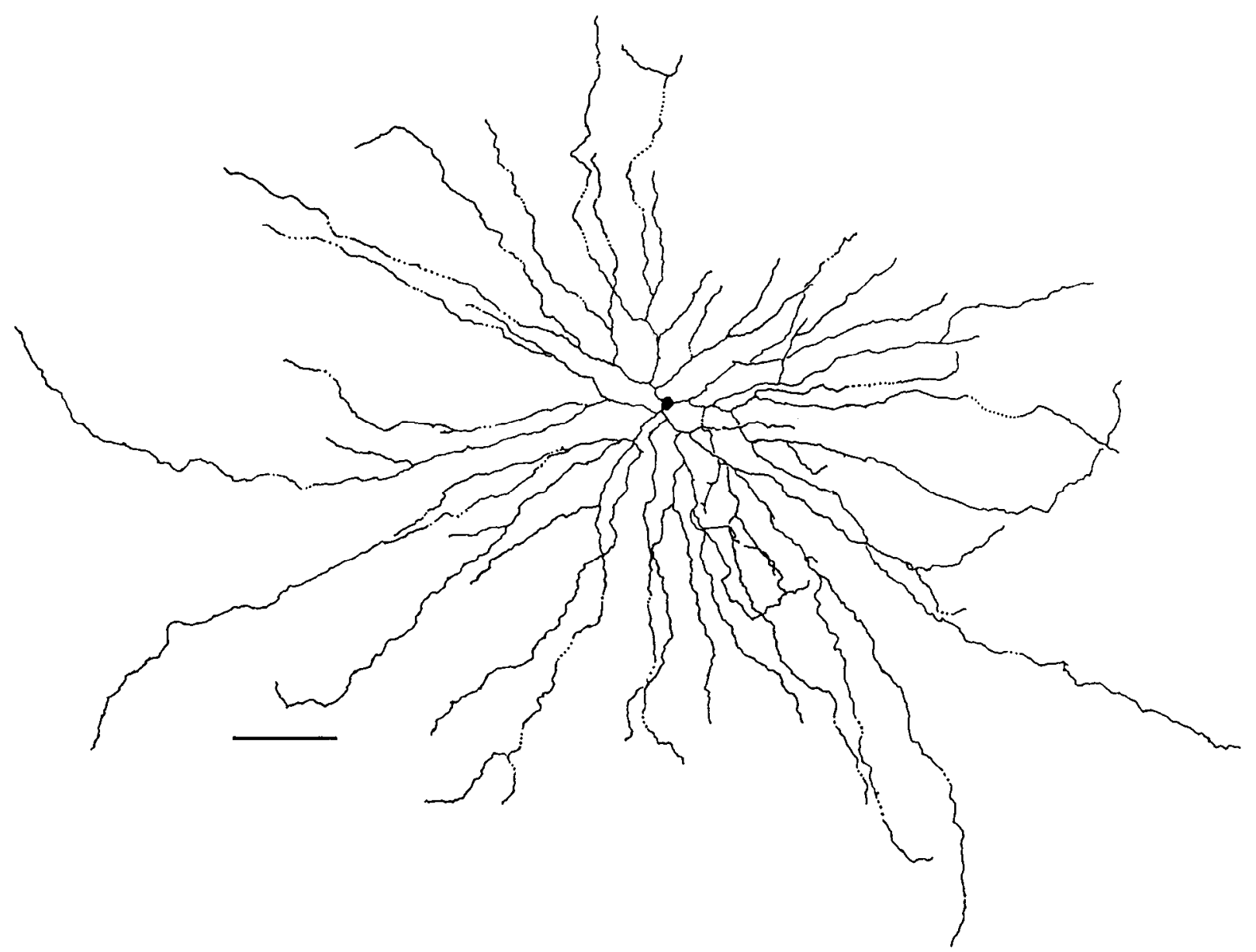

Figure 8. Arborization of a DAB-reacted type 3 cell in the outer plexiform layer. Dotted lines indicate places where the processes were partially obscured by underlying type 1 and type 2 cell bodies. The widest diameter of this dendritic arbor is $1160 \mu \mathrm{m}$. Scale, $100 \mu \mathrm{m}$.

and analysis was carried out by the method of Wässle and Reimann (1978). The spacing of the displaced cells was studied from the maps shown in Figure $13, A$ and $B$, for a $155.74 \mathrm{~mm}^{2}$ region encompassing much of the retina ventral to the visual streak. (The population of type 3 cells was too small for nearestneighbor analysis.) The observed nearest-neighbor distributions are shown in Figure 14, together with the distributions expected were the same number of cells positioned at random. For type 1 and type 2 cells the observed distributions are more regular than chance. The distribution of displaced type 2 cells approximated a random distribution. The population of displaced type 1 cells seemed to contain more pairs of nearby cells than predicted for a random distribution. If one takes as an index of regularity the ratio of the mean to the SD (Wässle and Reimann, 1978), the conventional type 1 cells are the most regular (ratio, 2.96 ) and the displaced type 1 cells the least (ratio, 1.55).

From the total population of injected neurons, 48 type 1 cells were drawn for further study. Their locations are shown on a schematic retina in Figure 15. Drawings of the cells indicated by numbers in the schematic are shown in Figure 16. The diameters of the dendritic fields of all of the drawn cells were measured and are shown in Figure 17. The dendritic diameters ranged from 271 to $543 \mu \mathrm{m}$. From the dendritic spread and the cell density (Fig. 11), it is immediately apparent that the dendritic fields of these cells overlap extensively. The diameter of the dendritic fields, however, varied quite widely (Fig. 17). Near the visual streak, for example, the largest dendritic field diameter was $543 \mu \mathrm{m}$ and the smallest was $356 \mu \mathrm{m}$. As will be discussed later, the meaning of this variation is not clear. Because of it, the exact overlap of the cells (coverage) can only be approximated. If one computes coverage from the largest cell observed (in the central retina), the coverage factor (cell density $\times$ dendritic field area) is 88 . If one takes the smallest, it is 68 .

Although fewer of the type 2 cells were filled with Lucifer yellow, their dendritic field diameters were in the same range as those of the type 1 cells (see Fig. 5). Since their density is also similar, these cells must also have a great overlap. Taken together, there are more than 1300 type 1 and type 2 cells $/ \mathrm{mm}^{2}$ in the central retina. It is not surprising that the plexus formed at the base of the inner plexiform layer by their commingled dendrites is so densc.

The contribution of the type 3 cells to that plexus must be slight, by comparison to type 1 and 2 cells, because the type 3 cells are infrequent; but their arborization in the outer retina is of some interest. Because of the limited size of the field that could be irradiated, it was never possible to see all of the dendrites of a type 3 cell at once. In cases where the cell body happened to be located near the edge of the irradiated field, however, the total radius of the dendrites could be seen. Since the dendritic fields of these cells are essentially round, the radii allow estimation of the dendritic field diameters. They were estimated in this way for 9 cells. The mean was $853 \mu \mathrm{m}$ (range, $525-1400+$ ). Because the sample is small (and is biased toward the smaller cells), it does not allow calculation of a coverage factor. It is possible, however, to estimate its rough limits. If one takes as an upper limit of cell density the highest local density observed for the cells, a dendritic field diameter of 853 $\mu \mathrm{m}$ would yield a coverage of 3.43 . If one takes as a conservative 


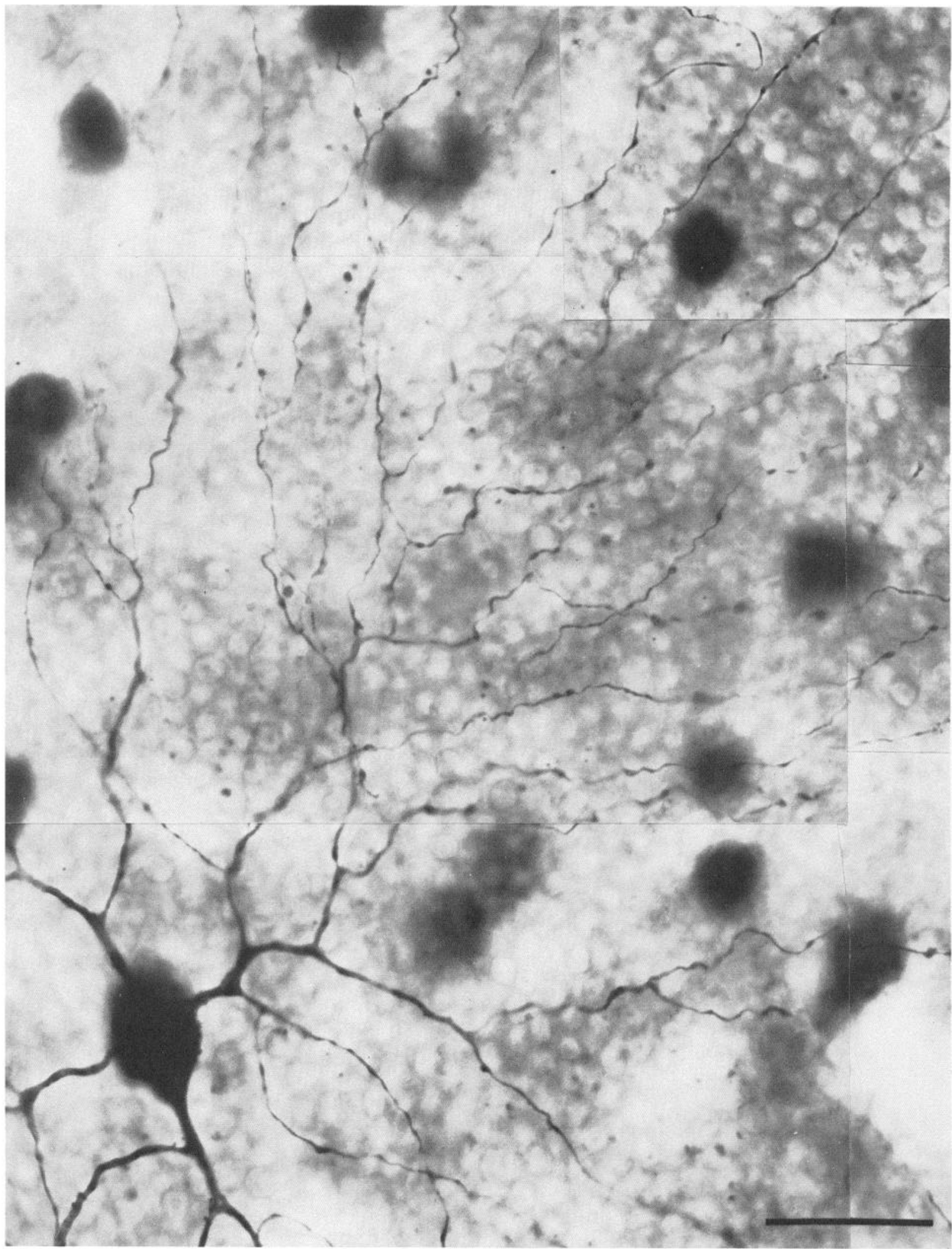

Figure 9. Part of the outer plexiform layer arborization of a type 3 cell. The processes are fine, branch frequently, and contain many varicosities. Scale, $30 \mu \mathrm{m}$ 


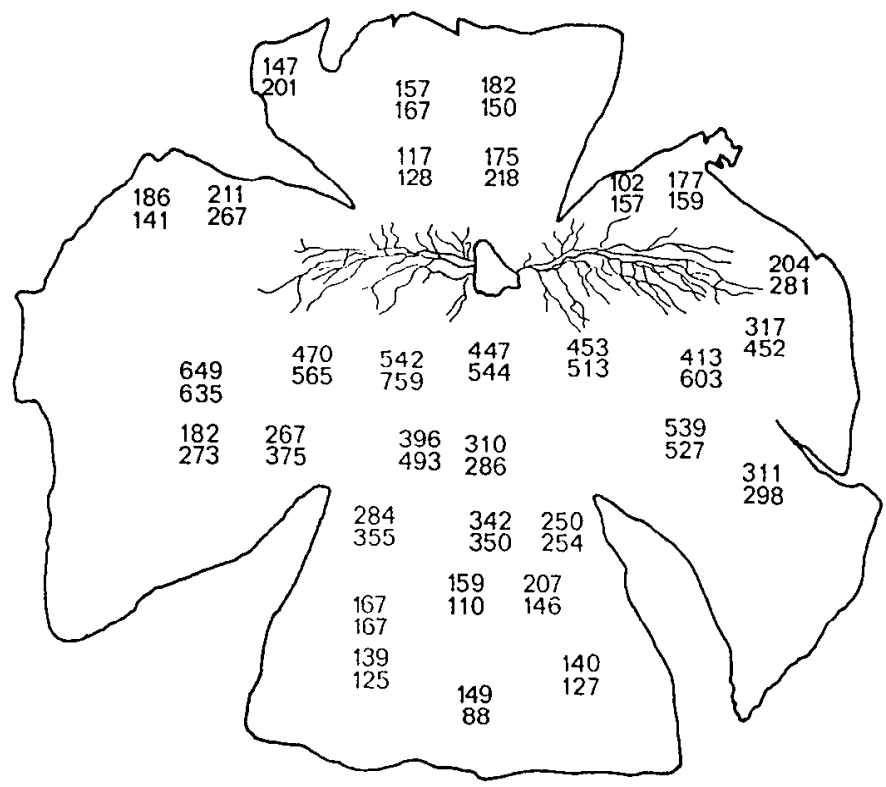

Figure 10. Number of type 1 cells (upper numbers) and type 2 cells (lower numbers) per $\mathrm{mm}^{2}$ following DAB reactions at various retinal locations.

estimate a distribution of approximately 300 type 3 cells across a rabbit retina of average area $400 \mathrm{~mm}^{2}$, then the average density of the cells is $0.75 / \mathrm{mm}^{2}$ and the coverage is 0.43 . This value is the lower limit.

\section{Discussion}

In its overall pattern, the labeling of the retina by $5,7-\mathrm{DHT}$ was much as described by Ehinger and Florén (1976, 1980). A majority of the cells have the conventional position of amacrine cells; a smaller group has cell bodies displaced to the ganglion

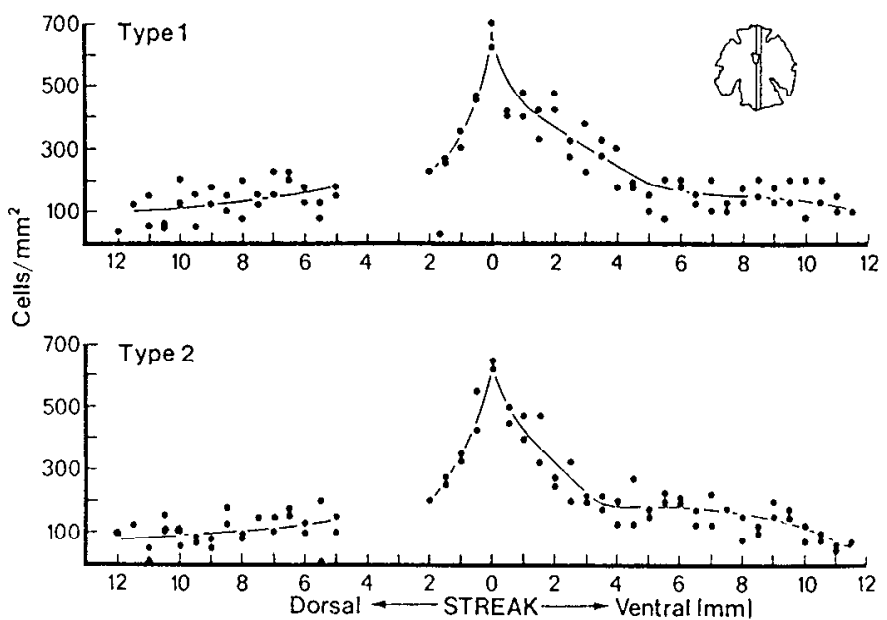

Figure 11. Densities of fluorescent type 1 and type 2 cells measured along 2 vertical swaths. The densities of both cell types peak at about 650 cells $/ \mathrm{mm}^{2}$ in the visual streak and fall to $100 \mathrm{cells} / \mathrm{mm}^{2}$ in the periphery.

cell layer; and there is an accumulation of fluorescence at the base of the inner plexiform layer. Two things are added here. 'The first is a description of the individual cells' morphologies (from Lucifer yellow injections), which allowed us to see that there are several subtypes of indoleamine-accumulating cell. The second is a simultaneous view of the complete morphologies of all of the cells. This allows recognition of the interrelations among them - a view of the cells as a system, rather than as isolated instances (Fig. 18).

The method that made the latter possible was the photoconversion of 5,7-DHT fluorescence to an insoluble DAB product. As has been described, this reaction is quite specific: only cells labeled by 5,7-DHT are reactive, and the resulting stain shows the cells far more clearly than does fluorescent labeling. We have not investigated the mechanism of the reaction system-

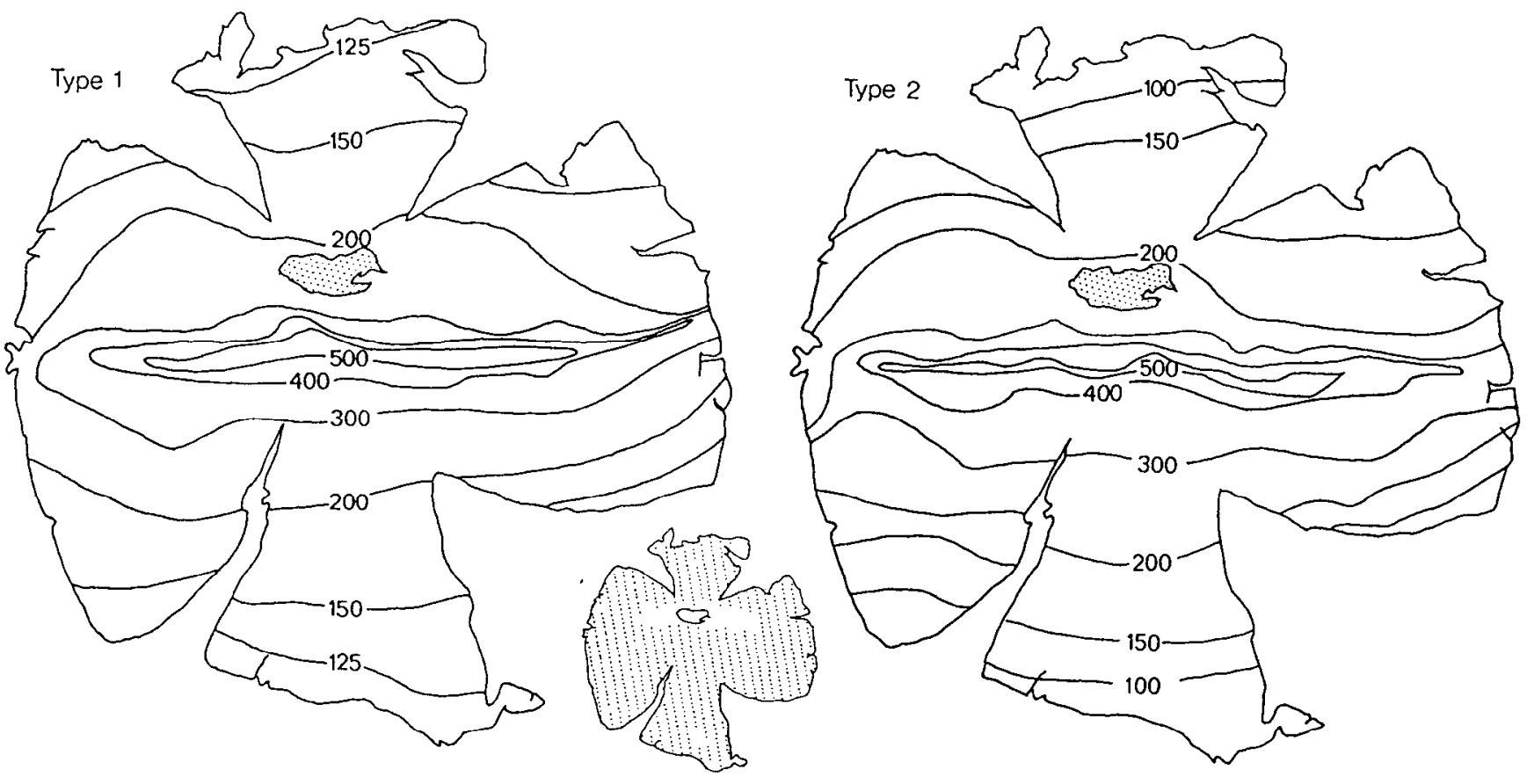

Figure 12. Isodensity contour maps for type $1(A)$ and type $2(B)$ cells. The 718 retinal locations at which cells were counted are shown on the smaller whole-mount inset between the 2 maps. Isolated instances of densities in excess of $600 \mathrm{cells} / \mathrm{mm}^{2}$ (not shown) were present within the 500 cell contour line for both cell types. 


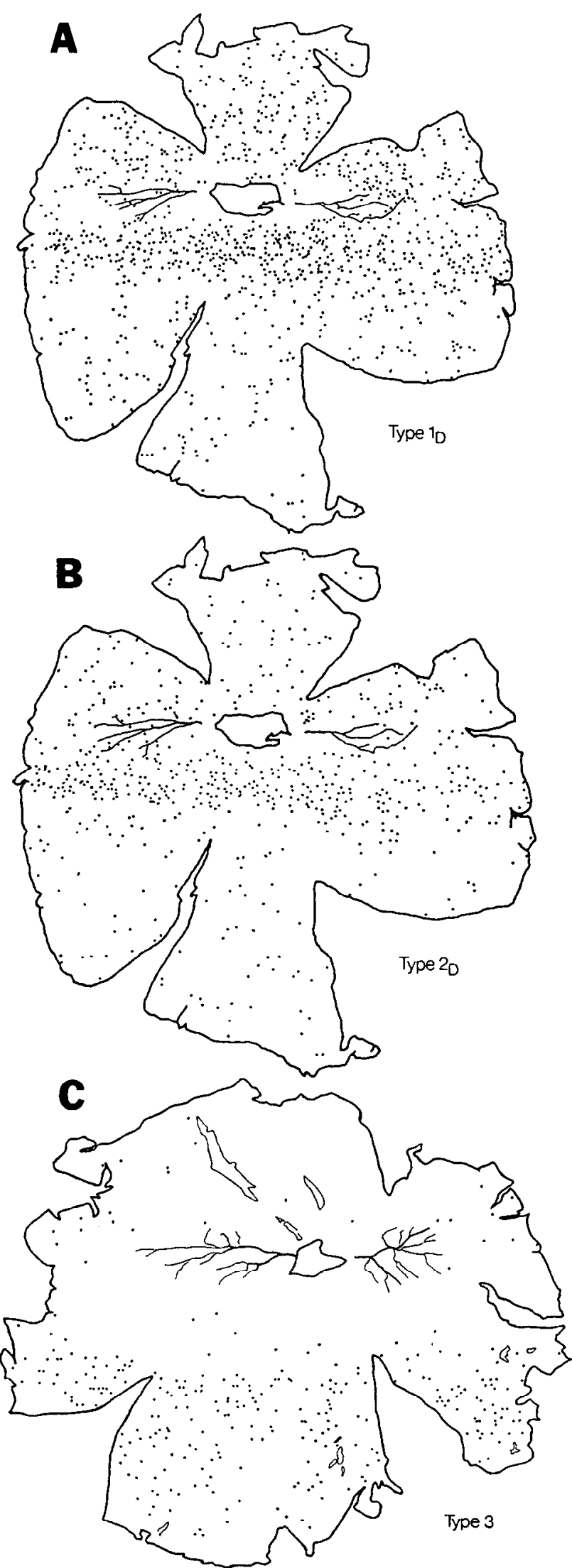

Figure 13. Maps showing the location of each displaced $(A)$ type 1 cell (type $1_{D}$ ), displaced $(B)$ type 2 cell (type $\left.2_{D}\right)$, and $(C)$ type 3 cell.
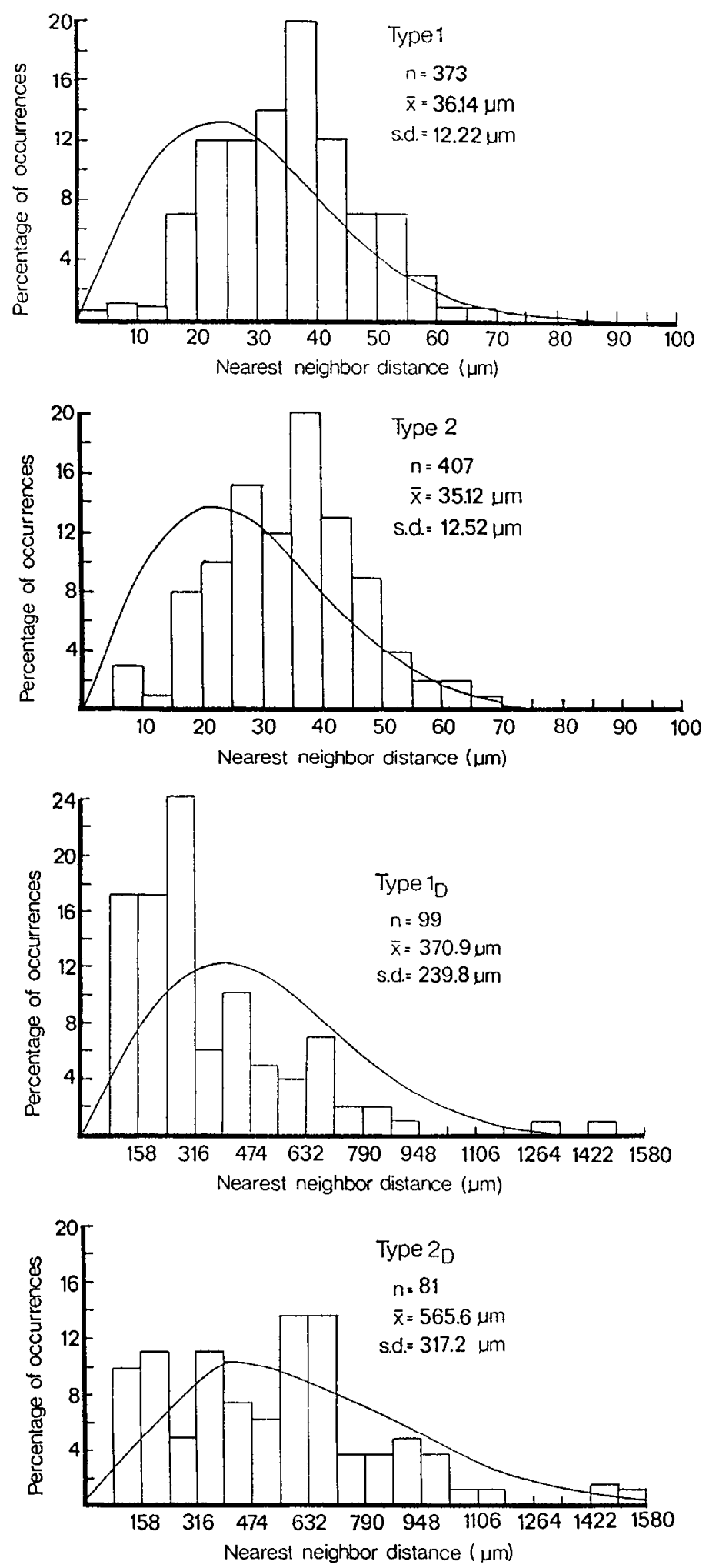

Figure 14. Nearest-neighbor histograms for type 1, type 2, type 1 displaced, and type 2 displaced cells. The curves show the distributions expected if the members of each cell population were positioned at random. The type 1 and type 2 cells are more regular than their respective random distributions. The population of displaced type 1 cells contained more cells with short cell-to-cell distances than predicted by chance. The displaced type 2 cells were positioned roughly at random. 
atically, but it appears similar to the one that occurs during the photooxidation of Lucifer yellow described by Maranto (1982). (In fact, we discovered that 5,7-DHT could be reacted in this way while attempting Maranto's method on Lucifer-filled cells in tissue that happened also to contain cells labeled with 5,7DHT fluorescence.) Maranto suggested that the reaction is an oxidation of $\mathrm{DAB}$ to an insoluble product similar to the one created during the enzymatic action of HRP on hydrogen peroxide. Both the Lucifer reaction and the 5,7-DHT reaction are prevented by the addition of ascorbate to the reaction mixture. Mechanisms by which excitation of the fluorochromes could lead to oxidation of DAB can be imagined and might be worth systematic study, on the chance that DAB interconversions could be achieved for fluorescent molecules other than Lucifer yellow and 5,7-DHT.

Although the dendritic plexus is faintly visible from 5,7-DHT fluorescence alone, it was only in the DAB-reacted tissue that it could be examined in detail, and that processes could be traced from the cell bodies of individual neurons into it. All of the cells participate in the dendritic plexus. Because the cells could be compared side by side, though, it was easy to see that there are several indoleamine-accumulating cells-not just one. We have named the cells as distinct types-type 1, type 2, type 1 displaced, type 2 displaced, and type 3 -but not without some reluctance. Other things being equal, one seeks a taxonomy that minimizes the proliferation of retinal cell classes. Our fundamental reason for subdividing the cells is that their connections appear to be different. The type 1 cell and the type 2 cell have different numbers of varicosities. Since the varicosities are the primary sites of synaptic contact (Ehinger and Holmgren, 1979; Holmgren-Taylor, 1982), the density of synaptic contacts along the 2 cells' dendrites must be different. The size and shape of the varicosities are different, suggesting that the local patterns of contacts are different. Perhaps most important, the dendrites have different courses from the cell body to the dendritic plexus, providing the type 2 cell with more contacts in the outer part of the inner plexiform layer than the type 1 .

By a similar argument, we are forced to distinguish the type 1 and type 2 cells from their displaced counterparts. The displaced cells are not simply type 1 or type 2 cells that accidentally have their cell bodies in the ganglion cell layer. Their dendrites enter the dendritic plexus within a few microns of their cell body, while the dendrites of conventionally placed cells traverse $4 / 5$ of the width of the inner plexiform layer. The dendrites of the conventionally placed cells do not take the shortest possible course to the plexus. They slope for varying distances across the inner plexiform layer, and the sloping dendrites bear varicosities and make synaptic contacts (Ehinger and Holmgren, 1979; Holmgren-Taylor, 1982). The dendrites of the conventionally placed cells thus make synaptic contacts in parts of the inner plexiform layer that dendrites of the displaced cells never reach.

The fifth indoleamine-accumulating cell (type 3 ) has not been previously described in studies of amine fluorescence, nor do cells of this morphology appear to have been observed in Golgi material.

Once we had recognized their existence, type 3 cells were seen in all retinas. Their morphology was invariant. They are present in retinas from pigmented rabbits, as well as in the albinos that we usually studied. The intensity of their labeling with 5,7-DHT was the same as for the other indoleamine-accumulating cells. Although their numbers are relatively low, their branching is wide (for some it is more than $1200 \mu \mathrm{m}$ ). In addition, the density of their arborization in the outer plexiform layer exceeds the density of the lattices formed by many other retinal neurons (the dopamine and diaphorase-positive amacrines are examples; Brecha et al., 1984; Sandell, 1985; Tauchi and Masland, 1986). Although their cell bodies are widely spaced, it does not follow that their role in retinal function is minor.

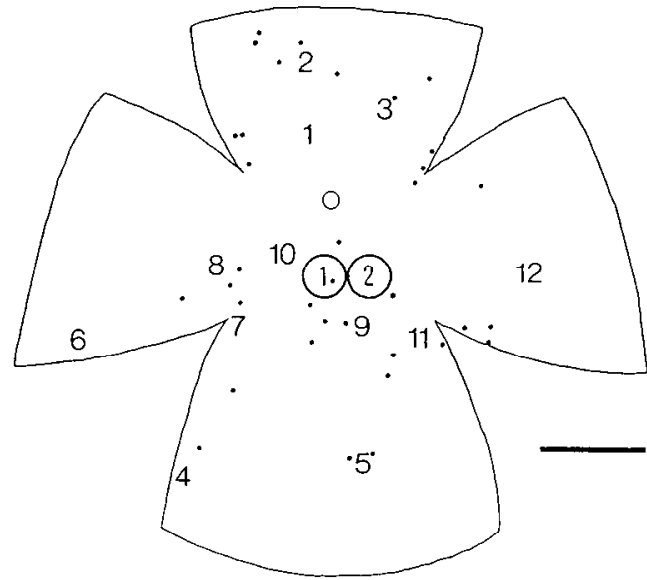

Figure 15. Schematic diagram showing the location of each type 1 cell injected with Lucifer yellow (dots). The circled numbers indicate the locations of the type 1 and type 2 cells illustrated in Figure 5. The other numbers show the locations of 12 Lucifer yellow-filled cells illustrated in Figure 16. Scale, $5 \mathrm{~mm}$.

Type 3 cells have neither the terminal tufts nor the soma shape that is characteristic of horizontal cells, and their descending processes exclude them from the family of horizontal cells as currently defined. Their morphology is also different from that of most bipolar cells. Many of their processes exit horizontally from the cell body. Their spread in the outer plexiform layer is at least 10 times more than that of even the giant bipolar cell described by Kolb et al. (1981), and their dendrites have a quite different morphology. Type 3 cells do not resemble any of the interplexiform cells described in the rabbit (Oyster and Takahashi, 1977), monkey (Boycott et al., 1975), cat (Gallego, 1971; Kolb, 1977; Kolb and West, 1977; Pourcho and Goebel, 1983), or fish (Marc and Liu, 1984) because the type 3 cell body is located at the scleral edge of the inner nuclear layer. Multiple dendrites exit directly from the cell body into the outer plexifom layer, while the ascending processes of previously described interplexiform cells arise from a dendrite in the inner plexiform layer or from a single stout process that leaves the scleral edge of the cell body. Finally, none of the existing interplexiform cells has branching in the outer plexiform layer comparable to that of the type 3 cell.

If the type 3 cell is not any previously described cell, what general class of cell, at least, does it belong to? The obvious choices are the classes of bipolar and interplexiform cells, but we cannot at present make a distinction-or decide whether the type 3 cell forms a new category altogether. A primary consideration would be the direction in which the cells conduct, and this will not be known until they have been examined by electron microscopy.

\section{Cell densities and coverages}

The type 1 and type 2 cells are very common - they are among the more numcrous amacrine cells yet encountered-and overlap substantially. It is the combination of frequency and overlap of the type 1 and 2 cells that creates such a dense mesh of dendrites at the base of the inner plexiform layer. While we hesitate to assign an exact coverage for the type 1 cell, it cannot be lower than 68 in the central retina and is probably morc. Whatever the true value, it is among the highest for any retinal cell thus far studied.

Our hesitation in assigning a coverage comes from the variability in dendritic field diameter of the injected cells. Although not essential to the fundamental conclusion (that the dendritic overlap is very great), the question is of some methodological interest. The best studied other retinal neurons (ganglion and 

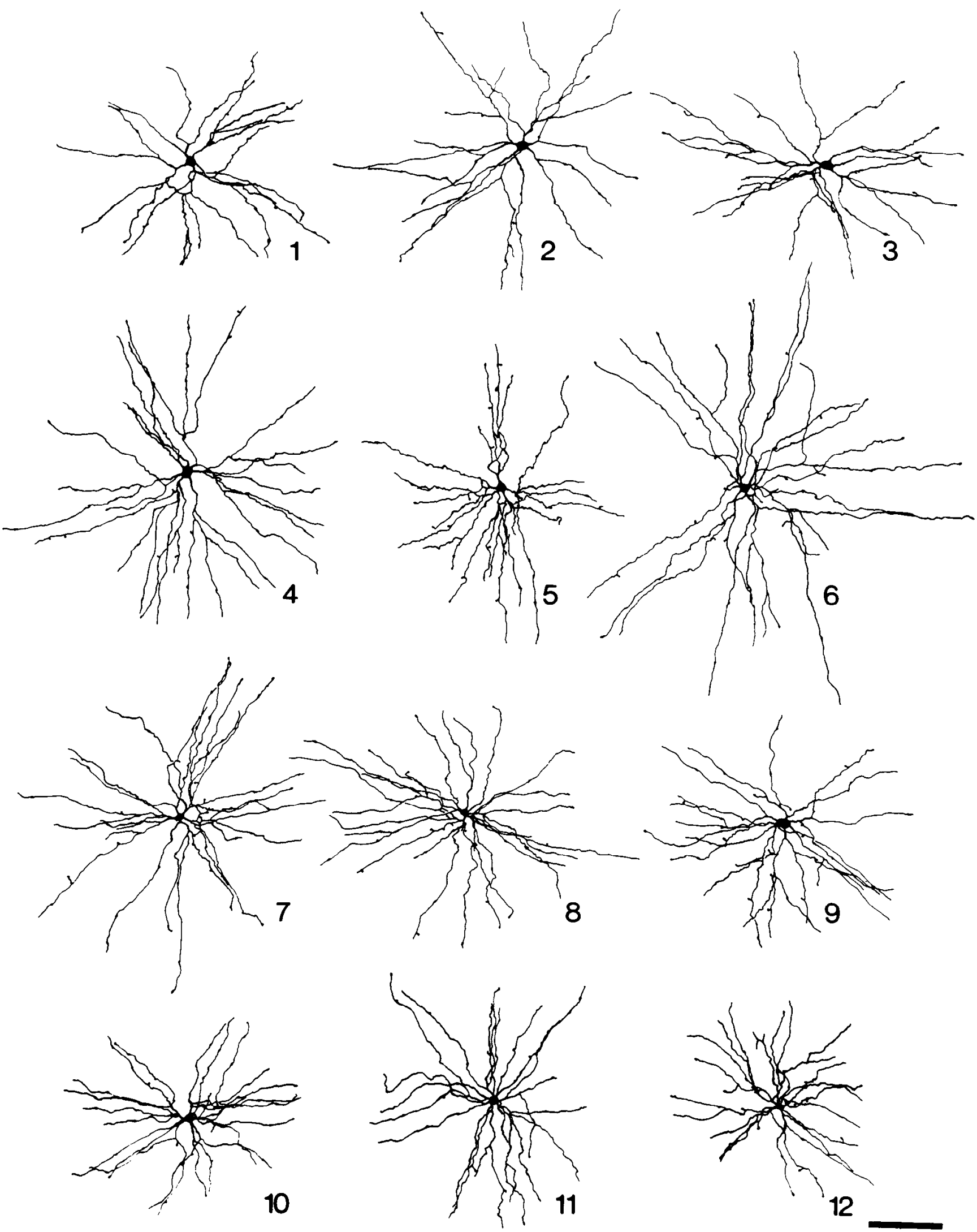

Figure 16. Drawings of 12 type 1 cells that had been injected with Lucifer yellow. The retinal locations of the cells are shown in Figure 15. Scale, $100 \mu \mathrm{m}$. 


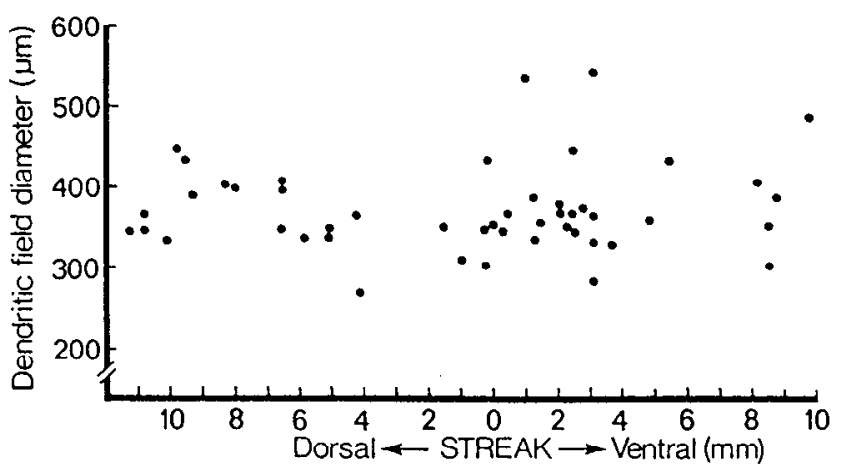

Figure 17. Dendritic diameter as a function of retinal eccentricity for 48 type 1 cells filled with Lucifer yellow.

horizontal cells of the cat, Wässle et al., 1978, 1981a, b; cholinergic amacrine cells in the rabbit, Tauchi and Masland, 1984; AII amacrines in the cat, Vaney, 1985) do not show this degree of variability. Of these, the most closely comparable to the indoleamine cells is the cholinergic neuron, another mediumficld rabbit amacrinc cell. The range of dendritic diameters for that cell, injected by the same method used here, is roughly $15 \%$ of the mean (Tauchi and Masland, 1984). One has the feeling that the sizes of retinal cells should be uniform. An obvious possibility is that the variation is due to variation in the extent to which Lucifer yellow fills the finest dendrities of the indoleamine accumulating cells. For that reason, it is tempting to consider the largest dendritic fields as the true representation, and compute coverage from them alone. To do so, however, is to treat the bias that the cells should be uniform as an established fact. For the moment, it seems best to reserve judgment.

The indoleamine-accumulating cells are the second case in which a large overlap has been found: The cholinergic amacrine cells have an overlap factor of 30 in the central retina and 70 in the periphery (Tauchi and Masland, 1984; Vaney, 1984). These overlaps are far in excess of those obtained for ganglion cells in the cat. At one time there was reason to think that a uniform, nonredundant blanketing of the retinal surface (as represented by the low coverages of ganglion cells) might identify functional classes of retinal neuron (Wässle and Reimann, 1978). Amacrine cells appear not to follow that rule.

A related question concerns the degree of order in the position of the cell bodies. What is observed, in this study and others, is that the spacing of amacrine cell bodies with respect to each other is less orderly than the spacing of ganglion cells (Brecha et al., 1984; Masland et al., 1984a; Oyster et al., 1985; Vaney et al., 1981). This is not surprising, when one remembers that amacrine cells tend to overlap each other. For cells that cover the retinal surface efficiently, such as the ganglion cells, cell position is important; irregular spacing would create holes in the dendritic mosaic (Wässle et al., 1981a, b). If the coverage is redundant, however, small variations in cell-to-cell spacing have little effect.

\section{The system of indoleamine-containing neurons}

To think of the indoleamine-accumulating cells only as individual morphological types would obscure one of their important aspects. It is that these cells have features in commonfeatures suggesting that they are better considered as a family of cells than as independent entities. The first is that they contain a common neurotransmitter, probably serotonin. Since different neurotransmitters have different actions in the synapses where they are used, the use of a common neurotransmitter implies that the cells also share some functional similarity. Furthermore, the large majority of those synapses lie in the same place. The cells participate in a single dendritic plexus, lying at the base of the inner plexiform layer. At the very least, this limits the other retinal neurons with which the cells can interact, since many amacrine and ganglion cells have few or no processes physically present at that level. Finally, Ehinger and Holmgren (1979) described the indoleamine-accumulating "cell" as having a quite repetitive synaptology, in which the large majority of synapses were reciprocal with rod bipolar cells at the base of the inner plexiform layer.

And yet the indoleamine-accumulating cells have 5 different shapes. As was discussed earlier, the displaced type 1 cell must have different connections from the type 1 cell, even though they are otherwise very similar: The conventionally placed type 1 cell has a substantial length of dendrite (and numerous varicosities) in the outer $4 / 5$ of the inner plexiform layer, while the displaced cell's whole dendritic tree is contained within the dendritic plexus. For the other cells the differences are even more pronounced. Outside the dendritic plexus, then, there is every reason to believe that the cells have different functional roles.

At their synapses with the rod bipolar terminal, the indoleamine-accumulating cells are in a position to control the primary portal for entry of rod-driven signals into the inner retina. Because they are numerous and form a dense dendritic plexus, their effect on the bipolar terminals would be expected to be substantial. One possibility is that their morphological diversity reflects varied sources of input to the control point. The type 3 cell, for example, could collect information from the outer retina and relay it to the reciprocal synapse; and the type 1 and type 2 cells can collect inputs from different sources in the inner plexiform layer. This is supported by electron microscopy, which shows that the indoleamine-accumulating cells are primarily postsynaptic at their synapses outside their dendritic plexus (Ehinger and Holmgren, 1979; Holmgren-Taylor, 1982). In this

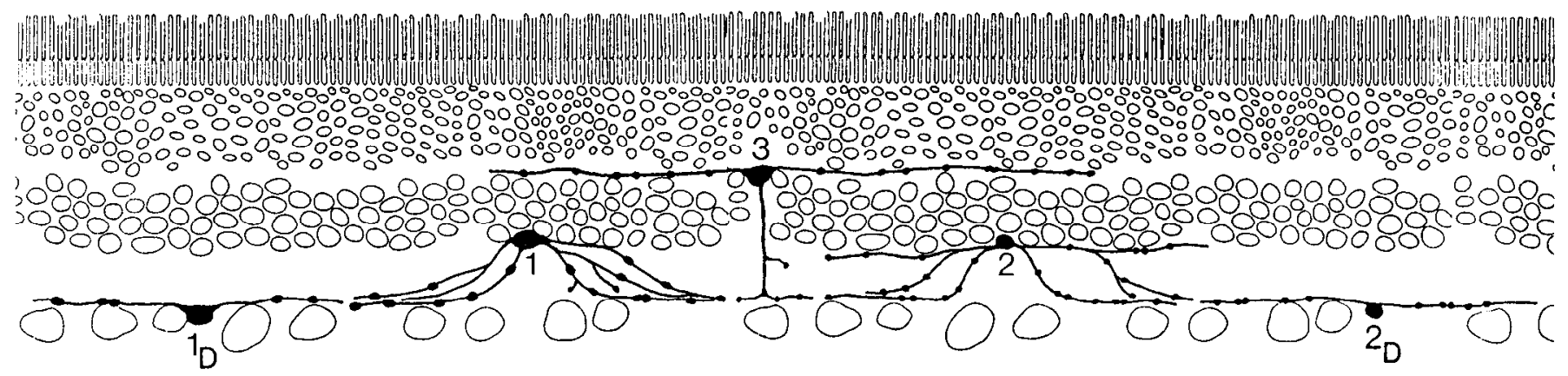

Figure 18. The indoleamine-accumulating neurons of the rabbit retina. To clarify the diagram, the lateral extent of all of the cells' dendrites is compressed. The cells' distinctive features are otherwise represented approximately to scale. 
analysis the synapse with the rod bipolar terminal would be considered as an effector site and the different morphologies of the indoleamine-accumulating cells different pathways to that site.

\section{Neuronal diversity in the retina}

While the function of the indoleamine-accumulating cells can be described only in outline, considering the cells as an interrelated family provides a useful conceptual starting point. Such groupings may be possible for other amacrines. For example, there are 2 cholinergic amacrine cells, 1 conventionally placed and 1 displaced (Masland and Mills, 1979). In their case, which is a relatively simple one, the cells are morphological mirror images and have symmetrical functions, one releasing neurotransmitter at stimulus onset and the other at offset (Famiglietti, 1983; Masland et al., 1984b). In the cat (Oyster et al., 1985), there are several dopaminergic amacrine cells; they share a common neurotransmitter and a morphology in which thin dendrites radiate from a plexus located at the junction of the inner plexiform and inner nuclear layers. A similar, though not identical, family of dopamine cells is present in the rabbit (Tauchi and Masland, 1986). There are other cases in which a single ncurotransmitter marks more than one morphological type of amacrine cell (Brecha et al., 1982; Famiglietti et al., 1980; Freed et al., 1983; Pourcho, 1980; Pourcho and Goebel, 1983), and for many of these cases there are at least preliminary indications of morphological similarities in addition to the cells' common biochemistry. $\Lambda$ s further morphological detail becomes available, grouping the cells into families may reduce the apparent complexity of the retina's amacrine cell populations.

\section{References}

Ames, A., III, and F. B. Nesbett (1981) In vitro retina as an experimental model of the central nervous system. J. Neurochem. 37: 867877.

Ames, A., III, and D. A. Pollen (1969) Neurotransmission in central nervous tissue: A study of isolated rabbit retina. J. Neurophysiol. 32: 424-442.

Blazynski, C., J. A. Ferrendelli, and A. I. Cohen (1985) Indoleaminesensitive adenylate cyclase in rabbit retina: Characterization and distribution. J. Neurochem. 45: 440-447.

Boycott, B. B., J. E. Dowling, S. K. Fisher, H. Kolb, and A. M. Laties (1975) Interplexiform cells of the mammalian retina and their comparison with catecholamine-containing retinal cells. Proc. R. Soc. Lond. [Biol.] 191: 353-368.

Brecha, N. (1983) Retinal neurotransmitters: Histochemical and biochemical studies. In Chemical Neuroanatomy, P. C. Emson, ed., pp. 85-129, Raven, New York.

Brecha, N. C., and H. J. Karten (1983) Identification and localization of neuropeptides in the vertebrate retina. In Brain Peptides, D. T. Krieger and M. J. Brownstein, eds., pp. 437-462, Wiley, New York.

Brecha, N. C., A. Hendrickson, I. Florén, and H. J. Karten (1982) Localization of substance P-like immunoreactivity within the monkey retina. Invest. Ophthalmol. Vis. Sci. 2: 147-153.

Brecha, N. C., C. W. Oyster, and E. S. Takahashi (1984) Identification and characterization of tyrosine hydroxylase immunoreactive amacrine cells. Invest. Ophthalmol. Vis. Sci. 25: 66-70.

Brunken, W. J., and N. W. Daw (1985) The role of indoleamines in visual processing in the rabbit retina. Soc. Neurosci. Abstr. 11:241.

Ehinger, B. (1983) Connexions between retinal neurons with identified neurotransmitters. Vision Res. 23: 1281-1291.

Ehinger, B., and L. Åberg (1981) Density of amine accumulating neurons in rabbit and guinea pig retina. Acta Physiol. Scand. 112:111112

Ehinger, B., and I. Florén (1976) Indoleamine accumulating neurons in the retina of rabbit, cat, and goldfish. Cell Tissue Res. 175: 3748 .

Ehinger, B., and I. Florén (1978) Quantitation of the uptake of indoleamines and dopamine in the rabbit retina. Exp. Eye Res. 26: 111.
Ehinger, B., and I. Florén (1980) Retinal indoleamine accumulating neurons. Neurochem. Int. 1: 209-229.

Ehingcr, B., and I. Holmgren (1979) Electron microscopy of the indoleamine-accumulating neurons in the retina of the rabbit. Cell Tissue Res. 197: 175-194.

Ehinger, B., I. Florén, and K. Tornquist (1982) Autoradiography of $\left({ }^{3} \mathrm{H}\right)-5$-hydroxytryptamine uptake in the retina of some mammals. Albrecht Von Graefes Arch. Klin. Exp. Ophthalmol. 218: 1-48.

Famiglietti, E. V., Jr. (1983) ON and OFF pathways through amacrine cells in mammalian retina: The synaptic connections of "starburst" amacrine cells. Vision Res. 23: 1265-1279.

Famiglietti, E. V., Jr., N. Brecha, and H. J. Karten (1980) Neural localization of substance P-like immunoreactivity in rabbit retina. Soc. Neurosci. Abstr. 6: 212

Florén, I (1979a) Indoleamine-accumulating neurons in the retina of the chicken and pigeon. Acta Ophthalmol. 57: 198-210.

Florén, I. (1979b) Arguments against 5-hydroxytryptaminc as neurotransmitter in the rabbit retina. J. Neural Transm. 46: 1-15.

Floren, I., and H. C. Hansson (1980) Investigations into whether 5-hydroxytryptamine is a neurotransmitter in the retina of the rabbit and chicken. Invest. Ophthalmol. Vis. Sci. 19: 117-125.

Freed, M. A., Y. Nakamura, and P. Sterling (1983) Four types of amacrine cell in the cat retina that accumulate GABA. J. Comp. Neurol. 219: 295-304.

Furness, J. B., M. Costa, and W. W. Blessing (1977a) Simultaneous fixation and production of catecholamine fluorescence in central nervous tissue by perfusion with aldehydes. Histochem. J. 9: 745-750.

Furness, J. B., M. Costa, and A. J. Wilson (1977b) Water-stable fluorophores, produced by reaction with aldehyde solutions, for the histochemical localization of catechol- and indolethylamines. Histochemistry 52: 159-170.

Gallego, A. (1971) Horizontal and amacrine cells in the mammal's retina. Vision Res. 11(suppl): 33-50.

Holmgren-Taylor, I. (1982) Electron microscopical observations on the indoleamine-accumulating neurons and their synaptic connections in the retina of the cat. J. Comp. Neurol. 208: 144-156.

Hughes, A. (1975) A quantitative study of cat retinal ganglion cell topography. J. Comp. Neurol. 163: 107-128.

Kolb, H. (1977) Organization of the outer plexiform layer in the retina of the cat: Electron microscopic observations. J. Neurocytol. 6: 131153.

Kolb, H., and R. W. West (1977) Synaptic connections of the interplexiform cell in the retina of the cat. J. Neurocytol. $6: 155-170$.

Kolb, H., R. Nelson, and A. Mariani (1981) Amacrine cells, bipolar cells, and ganglion cells of the cat retina: A Golgi study. Vision Res. 21: $1081-1114$.

Maranto, A. R. (1982) Neuronal mapping: A photooxidation reaction makes Lucifer Yellow useful for electron microscopy. Science 217: 953-955.

Marc, R. E., and W.-L. S. Liu (1984) Horizontal cell synapses onto glycine-accumulating interplexiform cells. Nature 312: 266-269.

Masland, R. H., and C. J. Livingstone (1976) Effect of stimulation with light on the synthesis and release of acetylcholine by an isolated mammalian retina. J. Neurophysiol. 39: 1210-1219.

Masland, R. H., and J. W. Mills (1979) Autoradiographic identification of acetylcholine in the rabbit retina. J. Cell. Biol. 83: 159-178.

Masland, R. H., J. W. Mills, and S. A. Hayden (1984a) Acetylcholinesynthesizing amacrine cells: Identification and selective staining by using radioautography and fluorescent markers. Proc. R. Soc. Lond. [Biol.] 223: 79-100.

Masland, R. H., J. W. Mills, and C. Cassidy (1984b) The functions of acetylcholine in the rabbit retina. Proc. R. Soc. Lond. [Biol.] 223: 121-139.

Mitchell, C. K., and D. A. Redburn (1985) Analysis of the pre- and postsynaptic factors of the serotonin system in rabbit retina. J. Cell. Biol. 100: 64-73.

Negishi, K., T. Teranishi, and S. Kato (1984) Regional density of monoamine accumulating amacrine cells in the rabbit retina. Neurosci. Lett. 45: 27-32.

Osborne, N. N. (1981) Binding of ${ }^{3} \mathrm{H}$-serotonin to membranes of the bovine retina. Exp. Eye Res. 33: 371-380.

Osborne, N. N. (1984) Indoleamines in the eye with special reference to the serotonergic neurones of the retina. Prog. Retinal Res. 3: 61104. 
Osborne, N. N., and S. Patel (1984) Postnatal development of serotonin-accumulating neurones in the rabbit retina and an immunohistochemical analysis of the uptake and release of serotonin. Exp. Eye Res. 38: 611-620.

Oyster, C. W., and E. S. Takahashi (1977) Interplexiform cells in rabbit retina. Proc. R. Soc. Lond. [Biol.] 197: 477-484.

Oyster, C. W., E. S. Takahashi, M. Cilluffo, and N. C. Brecha (1985) Morphology and distribution of tyrosine hydroxylase-like immunoreactive neurons in the cat retina. Proc. Natl. Acad. Sci. USA 82: $6335-6339$

Pourcho, R. G. (1980) Uptake of $\left({ }^{3} \mathrm{H}\right)$ glycine and GABA by amacrine cells in the cat retina. Brain Res. 198: 333-346.

Pourcho, R. G., and D. J. Goebel (1983) Neuronal subpopulations in cat retina which accumulate the GABA agonist, $\left({ }^{3} \mathrm{H}\right)$ muscimol: A combined Golgi and autoradiographic study. J. Comp. Neurol. 219: 25-35.

Redburn, D. A. (1984) Serotonin systems in the inner and outer plexiform layers of the vertebrate retina. Fed. Proc. 43: 2699-2703.

Sandell, J. H. (1985) NADPH diaphorase cells in the mammalian inner retina. J. Comp. Neurol. 238: 466-472.

Tauchi, M., and R. H. Masland (1984) The shape and arrangement of the cholinergic neurons in the rabbit retina. Proc. R. Soc. Lond. [Biol.] 223: 101-119.

Tauchi, M., and R. H. Masland (1985) Local order among the dendrites of an amacrine cell population. J. Neurosci. 5: 2494-2501.

Tauchi, M., and R. H. Masland (1986) Subpopulations of catecholaminergic neurons in the rabbit retina. Soc. Neurosci. Abstr. 11: 198.
Thier, P., and H. Wässle (1984) Indoleamine-mediated reciprocal modulation of on-centre and off-centre ganglion cell activity in the retina of the cat. J. Physiol. (Lond.) 351: 613-630.

Thomas, T. N., and D. A. Redburn (1979) 5-Hydroxytryptamine-A neurotransmitter of bovine retina. Exp. Eye Res. 28: 55-61.

Thomas, T. N., and D. A. Redburn (1980) Serotonin uptake and release by subcellular fractions of bovine retina. Vision Res. $20: 1-8$.

Vaney, D. I. (1984) "Coronate" amacrine cells in the rabbit retina have a "starburst" dendritic morphology. Proc. R. Soc. Lond. [Biol.] 220: $501-508$

Vaney, D. I. (1985) The morphology and topographic distribution of AII amacrine cells in the cat retina. Proc. R. Soc. Lond. [Biol.] 224: $475-488$

Vaney, D. I., L. Peichl, and B. B. Boycott (1981) Matching populations of amacrine cells in the inner nuclear and ganglion cell layers of the rabbit retina. J. Comp. Neurol. 199: 373-391.

Wässle, H., and H. J. Reimann (1978) The mosaic of nerve cells in the mammalian retina. Proc. R. Soc. Lond. [Biol.] 200: 441-461.

Wässle, H., L. Peichl, and B. B. Boycott (1978) Topography of horizontal cells in the retina of the domestic cal. Proc. R. Soc. Lond. [Biol.] 203: 269-291.

Wässle, H., L. Peichl, and B. B. Boycott (1981a) Morphology and topography of on- and off-alpha cells in the cat retina. Proc. R. Soc. Lond. [Biol.] 212: 157-175.

Wässle, H., L. Peichl, and B. B. Boycott (1981b) Morphology and mosaic of on- and off-beta cells in the cat retina and some functional considerations. Proc. R. Soc. Lond. [Biol.] 212: 177-195. 